\section{Rapid Sand Filtration of Recycled Irrigation Water Controlled Pythium Root Rot of Poinsettia in Greenhouse}

\author{
Sangho Jeon ${ }^{1,2}$, Charles S. Krasnow ${ }^{1}$, Gemini D. Bhalsod ${ }^{1,3}$, \\ Blair R. Harlan ${ }^{1}$, Mary K. Hausbeck ${ }^{1}$, Steven I. Safferman ${ }^{4}$, \\ and Wei Zhang ${ }^{1}$
}

\section{AdDitional INDEX wORDs. activated carbon, fungicide, etridiazole, Euphorbia pulcherrima, pathogen}

Summary. Pythium species incite crown and root rot and can be highly destructive to floriculture crops in greenhouses, especially when irrigation water is recycled. This study assessed the performance of rapid filtration of recycled irrigation water for controlling pythium root rot of poinsettia (Euphorbia pulcherrima) in greenhouses. Two greenhouse experiments investigated the effect of filter media type (sand and activated carbon), fungicide application (etridiazole), and pathogen inoculum source (infested growing media and infested irrigation water). Rapid sand filtration consistently controlled pythium root rot of poinsettia. Significant improvements in height, weight, root rot severity, and horticultural quality were observed for the plants in the sand filter treatment, compared with the inoculated control plants. However, the activated carbon filter removed essential nutrients from the irrigation water, resulting in plant nutrient deficiency and consequently leaf chlorosis, thus reducing plant weight, height, and horticultural quality. The etridiazole application did not completely prevent root infection by Pythium aphanidermatum, but plant weight, height, and horticultural quality were not negatively affected. $P$. aphanidermatum spread from infested growing media to healthy plants when irrigation water was recycled without filtration. Rapid sand filtration appears to have the potential to limit the spread of $P$. aphanidermatum that causes root rot of greenhouse floriculture crops.

Received for publication 16 Nov. 2018. Accepted for publication 14 June 2019

Published online 7 August 2019

${ }^{1}$ Department of Plant, Soil and Microbial Sciences, Michigan State University, East Lansing, MI 48824

${ }^{2}$ National Institute of Agricultural Sciences, Rural Development Administration, Wanju 54875, Republic of Korea

${ }^{3}$ Cook County Unit, University of Illinois Extension, Arlington Heights, IL 60004

${ }^{4}$ Department of Biosystems and Agricultural Engineering, Michigan State University, East Lansing, MI 48824

This research was supported in part by the NonAssistance Cooperative Agreement 58-8062-5-036 between the USDA-ARS Plant Protection Research Unit, Ithaca, NY, the Michigan State University Department of Plant, Soil and Microbial Sciences, E. Lansing, MI, as part of the Floriculture and Nursery Research Initiative, the American Floral Endowment, and Michigan State University AgBioResearch. We thank Sheila D. Linderman for proofreading and editing of the manuscript.

S.J., C.S.K., and G.D.B. are Graduate Research Assistants.

B.R.H. is a Research Technician.

M.K.H. is a University Distinguished Professor.

S.I.S. and W.Z. are Associate Professors.

W.Z. is the corresponding author. E-mail: weizhang@ msu.edu.

This is an open access article distributed under the CC BY-NC-ND license (https://creativecommons.org/ licenses/by-nc-nd $/ 4.0 /$ ).

https://doi.org/10.21273/HORTTECH04226-18
$\mathrm{F}$ States have an estimated wholesale value of $\$ 4.4$ billion and include a diverse assortment of bedding plants, potted flowers, and cut flowers. Poinsettia contributed a wholesale value of $\$ 140$ million in 2015 (U.S. Department of Agriculture, 2016) and are one of the top potted flowering plants in the United States (Dole and Wilkins, 2005). In the greenhouse production of floriculture crops, recirculating loriculture crops in the United irrigation systems have been widely adopted to lower water usage and conserve fertilizers that can otherwise be lost via discharge runoff (Bush et al., 2003; Hong et al., 2003; MacDonald et al., 1994; Sanogo and Moorman, 1993). This is especially true for greenhouses with large water use [1.9-3.8 million liters per day (Meador et al., 2012)]. Ebband-flow and flood-floor irrigation systems typically recirculate the irrigation water and are used to maximize production area and decrease labor costs (Ehret et al., 2001; van Der Gaag et al., 2001). In this type of system, irrigation water is pumped from a water reservoir to flood the floor or bench at a specified water level for a desired duration, and then drained back (often by gravity flow) to the reservoir for recycling in the next irrigation event. Although recycling irrigation water offers many benefits to greenhouse growers, plant pathogens can also be disseminated in the recycled irrigation water (Ehret et al., 2001). Thus, limiting pathogen transmission in the recirculating irrigation systems is critical to the floriculture industry.

Pythium species and other water molds can be highly destructive to floriculture crops, and spread readily in irrigation water (Goldberg et al., 1992; Hong and Moorman, 2005; Lewis Ivey and Miller, 2013; Stanghellini et al., 1996a, 1996b). Pythium root rot causes plant stunting, wilt, and death and can also reduce horticultural quality of infected crops (Tompkins and Middleton, 1950). The pathogen can become established in a greenhouse through infested soil and dust

\begin{tabular}{llll}
\hline $\begin{array}{l}\text { Units } \\
\text { To convert U.S. to SI, } \\
\text { multiply by }\end{array}$ & U.S. unit & SI unit & $\begin{array}{l}\text { To convert SI to U.S., } \\
\text { multiply by }\end{array}$ \\
\hline 29,574 & $\mathrm{fl} \mathrm{oz}$ & $\mu \mathrm{L}$ & $3.3814 \times 10^{-5}$ \\
29.5735 & $\mathrm{fl} \mathrm{oz}$ & $\mathrm{mL}$ & 0.0338 \\
0.3048 & $\mathrm{ft}$ & $\mathrm{m}$ & 3.2808 \\
3.7854 & $\mathrm{gal}$ & $\mathrm{L}$ & 0.2642 \\
2.54 & inch $(\mathrm{es})$ & $\mathrm{cm}$ & 0.3937 \\
25.4 & inch $(\mathrm{es})$ & $\mathrm{mm}$ & 0.0394 \\
1 & micron $(\mathrm{s})$ & $\mu \mathrm{m}$ & 1 \\
1 & $\mathrm{mmho} / \mathrm{cm}$ & $\mathrm{mS} \cdot \mathrm{cm}^{-1}$ & 1 \\
28.3495 & $\mathrm{oz}$ & $\mathrm{g}$ & 0.0353 \\
0.001 & $\mathrm{ppm}$ & $\mathrm{g} \cdot \mathrm{L}^{-1}$ & 1000 \\
1 & $\mathrm{ppm}$ & $\mathrm{mg} \cdot \mathrm{kg}^{-1}$ & 1 \\
1 & $\mathrm{ppm}$ & $\mathrm{mg} \cdot \mathrm{L}^{-1}$ & 1 \\
6.8948 & $\mathrm{psi}$ & $\mathrm{kPa}$ & 0.1450 \\
$\left({ }^{\circ} \mathrm{F}-32\right) \div 1.8$ & ${ }^{\circ} \mathrm{F}$ & ${ }^{\circ} \mathrm{C}$ & $\left({ }^{\circ} \mathrm{C} \times 1.8\right)+32$
\end{tabular}


(Stephens et al., 1983), contaminated seedlings, cuttings, or other plant material from propagation greenhouses (van Der Gaag et al., 2001). Surface water used for irrigation can also be infested with Pythium and Phytophthora species (Bush et al., 2003). Management of Pythium species is particularly challenging for potted plants; frequent irrigation and high moisture levels are ideal for the reproduction and transmission of this pathogen (Elmer et al., 2012). The high porosity of peat potting media may also facilitate the movement of zoospores, which are an important type of Pythium species inoculum (Oh and Son, 2008). Thus, Pythium species could be rapidly disseminated in a greenhouse via ebband-flow and flood-floor production systems (Hoitink, 1991), leading to crop damage and loss and requiring proactive management strategies.

Fungicide application is a common and important strategy to limit pythium root rot in greenhouse production (Moorman and Kim, 2004). Currently, two of the main fungicides used for pythium root rot control are etridiazole (Terrazole; OHP, Mainland, PA) and mefenoxam (Subdue Maxx; Syngenta Crop Protection, Greensborough, NC) (Moorman and Kim, 2004; Raabe et al., 1981). Etridiazole effectively reduced pythium root rot in poinsettia and easter lily (Lilium longiflorum) when applied as a soil drench (Ascerno et al., 1981; Hausbeck and Harlan, 2013b; Raabe et al., 1981). Also, etridiazole is one of the few commercial fungicides that are labeled for chemigation in ebb-and-flow and flood-floor irrigation systems. Mefenoxam can also limit crop loss from pythium root rot (Moorman et al., 2002). However, resistance to mefenoxam has developed in greenhouse populations of Pythium species, partly due to repeated fungicide use (Lookabaugh et al., 2015; Moorman and Kim, 2004; Moorman et al., 2002). Failure to control Pythium diseases using mefenoxam has been reported in greenhouses (Hausbeck and Harlan, 2013a; Moorman and Kim, 2004), and resistant isolates were detected in surface water used for irrigation (Carlson et al., 2004). Fungicide resistance has become a limiting factor in the control of pythium crown and root rot; alternative strategies (e.g., filtration) for pathogen control in irrigation water are needed (Hausbeck and Zhang, 2016).

Management of pathogens in recycled irrigation water has been a persistent challenge in greenhouse production. Ultraviolet radiation, heat treatment, chemical disinfection, ozonation, and filtration have been used to remove pathogens from irrigation water with varying degrees of success (Ehret et al., 2001; Hong and Moorman, 2005; Raudales et al., 2017). Many of these methods are cost-prohibitive to install and operate in commercial greenhouses. In contrast, filtration is a low-cost method that disinfests irrigation water by the physical removal of pathogens using granular porous media (e.g., sand) or membrane filters (Hong and Moorman, 2005). Membrane filtration can effectively remove zoospores if the membrane pore size is small enough to retain the motile zoospores that have a pleomorphic cell membrane (Schuerger and Hammer, 2009). Membrane filters with pore sizes of 1 and $5 \mu \mathrm{m}$ were able to remove the Pythium zoospores effectively from recirculating irrigation water in laboratory tests (Tu and Harwood, 2005). However, it is unknown whether this could be transferable to greenhouse settings. Diplanetism (where a zoospore encysts and releases a smaller motile zoospore) could decrease the efficacy of membrane filters (Erwin et al., 1983), although the occurrence of diplanetism in commercial greenhouses is unknown. Additional challenges with membrane filters are frequent leakage and membrane clogging and fouling (Ehret et al., 2001; Tu and Harwood, 2005), resulting in increased maintenance cost and decreased performance over time.

In contrast, deep-bed filtration (e.g., sand filtration) is cost-effective in terms of construction, operation, and maintenance. Slow filtration with granular materials has been studied as a means to remove Pythium species from the greenhouse irrigation water since the 1970s (Darling, 1977). However, it is not widely used in commercial U.S. greenhouses due to the slow water flow rate $[100-300$ $\mathrm{L} \cdot \mathrm{m}^{-2}$ per hour (Ehret et al., 2001)] that prohibits the movement of large volumes of water to multiple greenhouse ranges in an acceptable time period (Hong and Moorman, 2005).
Previous studies on the effectiveness of deep-bed filtration for removing plant pathogens from irrigation water have focused on slow sand filtration (Ehret et al., 2001; Hong and Moorman, 2005; Lee and Oki, 2013), whereas the effectiveness of rapid filtration on pathogen removal has not been well investigated. Additional data could help to determine whether this technique could be adopted to manage pathogens in irrigation water in greenhouses.

The objective of this study was to investigate the ability of rapid filtration systems to limit pythium root rot of potted poinsettia in greenhouses with ebb-and-flow and flood-floor irrigation systems. Six small-scale ebb-and-flow recirculating irrigation systems were constructed to simultaneously test the effect of filter media type (sand and activated carbon), fungicide application (etridiazole), and inoculum source mode (infested growth media vs. infested water) in two greenhouse experiments. Poinsettia was selected as a model crop because of its popularity as a potted flower, its economic importance, and the prevalence of pythium root rot outbreaks during its production. Pythium aphanidermatum was chosen because it is one of the most prevalent Pythium species in greenhouses and is more aggressive for developing disease symptoms on poinsettia than Pythium irregulare (Lookabaugh et al., 2015). This study was intended to show a proof-ofconcept to use rapid filtration systems in removing Pythium propagules from recirculating irrigation water.

\section{Materials and methods}

IRRIGATION AND FILTRATION SYSTEMS. Six small-scale irrigation systems were constructed to simulate the ebb-and-flow and flood-floor systems in greenhouse settings, each consisting of an ebb-and-flow bench $(8 \times 4 \mathrm{ft})$, an optional prefilter tank, an optional filter unit, and a holding tank, as shown in Fig. 1. The filter unit was designed as shown in Fig. 2 and was packed with either sand $[99.69 \%$ silica (Granusil; Unimin Corp., New Canaan, CT)] or activated carbon [AC (Filtrasorb 300; Calgon Carbon Corp., Moon Township, PA)]. Particle size distribution of the sand was $5.1 \% 297$ to $420 \mu \mathrm{m}$, $57.2 \% 420$ to $595 \mu \mathrm{m}, 36.1 \% 595$ to 


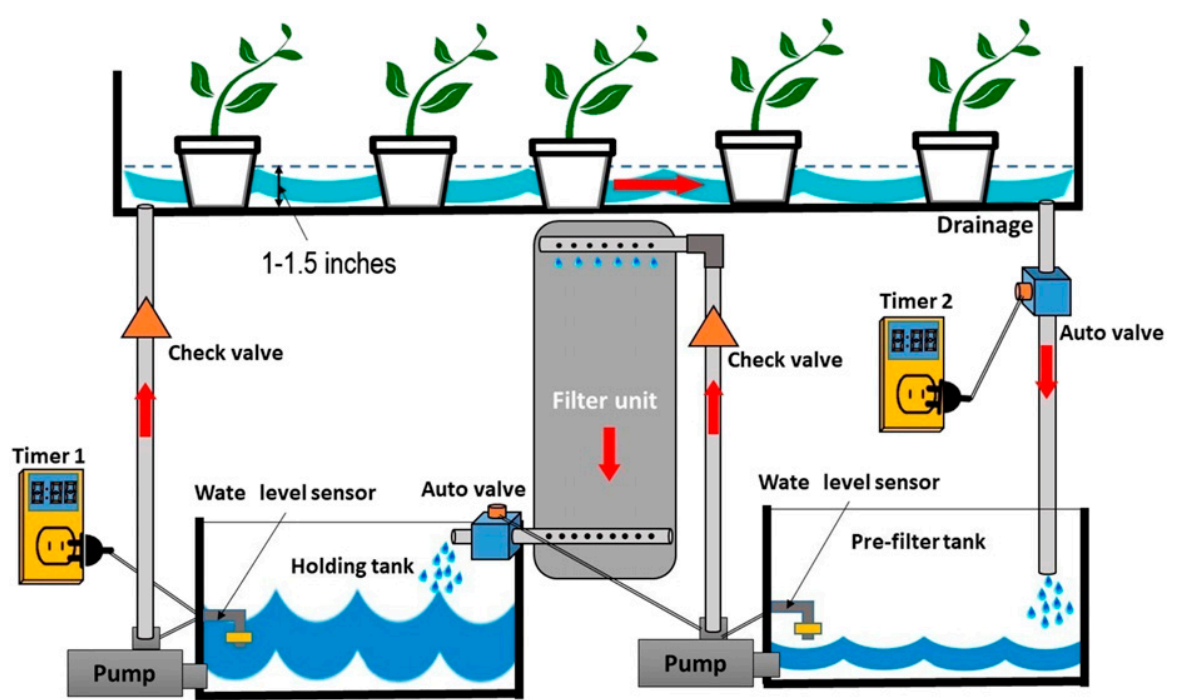

Fig. 1. Schematic of the small-scale ebb-and-flow irrigation system constructed in greenhouse; 1 inch $=2.54 \mathrm{~cm}$.

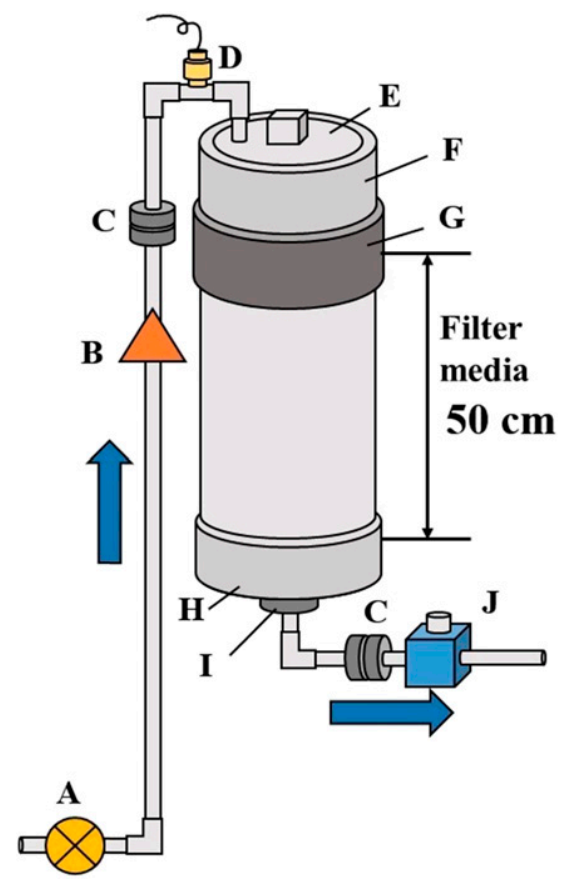

Fig. 2. Schematic of the filter unit: (A) 12-V water pump, (B) check valve, (C) union fitting, (D) pressure sensor, (E) polyvinyl chloride (PVC) plug fitting, (F) PVC adapter fitting, (G) PVC coupling, (H) PVC end cap fitting, (I) bulkhead fitting, and (J) motorized ball valve $(50 \mathrm{~cm}=19.7$ inches).

$841 \mu \mathrm{m}$, and $1.2 \% \geq 841 \mu \mathrm{m}$. The effective size of AC particles was 0.8 to $1.0 \mathrm{~mm}$. Detailed description of the irrigation systems and filter units is provided in Supplemental Materials S1 and S2. The irrigation systems allowed for automatic irrigation of potted plants placed in the bench via flooding according to a pre-designated schedule. These irrigation systems were subsequently used in the two greenhouse experiments.

Plant culture and irrigation WATER. One-month-old cuttings of 'Early Prestige Red' poinsettia were obtained from a local commercial greenhouse. The cuttings were transplanted into plastic nursery pots ( 6 inches diameter $\times 41 / 8$ inches tall) filled with peat potting mixture (Suremix; Sun Gro Horticulture, Galesburg, MI). Fifteen plants were randomly placed with about equal spacing on each of the six ebb-andflow benches to ensure a sufficient number of replicates for each treatment. In Expt. 2, the poinsettia cuttings were propagated from mature plants following a commercial propagation recommendation (Ecke et al., 2004) and planted into the nursery pots as described for the first experiment. The poinsettia plants were $\approx 6$ weeks old at the start of each experiment. Groundwater $(\mathrm{pH} 7.8 \pm 0.2)$ was used as the source of irrigation water. A $10 \mathrm{~N}-1.1 \mathrm{P}-7.9 \mathrm{~K}$ water-soluble fertilizer (JR Peters, Allentown, PA) was added to the irrigation water, and the initial nutrient concentration was $125 \mathrm{mg} \cdot \mathrm{L}^{-1}$ based on nitrogen. The prefilter tank (or the holding tank in some filter-free treatments) in the irrigation systems was filled with $120 \mathrm{~L}$ of the fertilized irrigation water. Plants were placed on the benchtops with irrigation in operation for $2 \mathrm{~d}$ to acclimate to the experimental condition before Pythium inoculation.

P. aphanidermatum isolates 106 and 319 were previously characterized for their sensitivity to etridiazole (Krasnow and Hausbeck, 2017) and were selected from the culture collection of M.K. Hausbeck at Michigan State University (MSU, East Lansing). They were maintained on corn meal agar (CMA) of $17 \mathrm{~g} \cdot \mathrm{L}^{-1}$. Before the study, the isolates were inoculated onto poinsettia stems and reisolated from the diseased stems to ensure virulence (Quesada-Ocampo and Hausbeck, 2010). Zoospores of $P$. aphanidermatum were produced according to a previously established method (Rahimian and Banihashemi, 1979). The Pythium isolates were grown on the V8 agar culture for $5 \mathrm{~d}$. The V8 agar culture was divided into six strips and separated into two sterile petri dishes of $100 \mathrm{~mm}$ diameter. The petri dishes were flooded with sterile distilled water (SDW), incubated at $30^{\circ} \mathrm{C}$ for $24 \mathrm{~h}$, drained, rinsed, and flooded with another $25 \mathrm{~mL}$ of SDW. After incubation for $10 \mathrm{~h}$ at ambient temperature $(21 \pm$ $2{ }^{\circ} \mathrm{C}$ ), the zoospores were released from the sporangia and transferred to a 2-L beaker half filled with SDW. To determine the concentration of the zoospore suspension, a $1-\mathrm{mL}$ aliquot was placed into a $1.7-\mathrm{mL}$ microcentrifuge tube, vortexed for $70 \mathrm{~s}$ to induce the zoospore encystment, and then a $10-\mu \mathrm{L}$ aliquot was pipetted onto a clean hemocytometer for counting (Bright-Line; Hausser Scientific, Horsham, PA). The concentration of initially produced zoospores was $1.7 \pm 0.9 \times 10^{4}$ zoospores $/ \mathrm{mL}$. The prepared suspensions of the motile biflagellate zoospores were equally split into five $500-\mathrm{mL}$ capped bottles and hand-shaken vigorously for $90 \mathrm{~s}$ to induce zoospore encystment. The suspension of encysted zoospores $\left(490 \mathrm{~mL}\right.$ of $1.7 \times 10^{4}$ zoospores $/ \mathrm{mL}$ ) was added to the prefilter or holding tank and thoroughly agitated with a wooden dowel. The resultant zoospore concentration in the irrigation water was $68 \pm 36$ zoospores $/ \mathrm{mL}$. During the greenhouse experiments, the irrigation water was passed through the filter unit and then stored in the holding tank before the next irrigation event. Two additional inoculations were 
made 2 and 4 weeks after the initiation of the experiment to increase disease pressure. To maintain a sufficient volume of water during each experiment, the irrigation water containing fertilizer was added when the water volume decreased to $\approx 70 \%$ to $80 \%$ of the initial volume.

Greenhouse experiments. Two greenhouse experiments were conducted in a temperature-controlled greenhouse that included six experimental treatments: 1) noninoculated irrigation water treatment without filtration or pathogen (- Control), 2) inoculated irrigation water treatment without filtration or fungicide (+ Control), 3) inoculated irrigation water treatment with the sand filter, 4) inoculated irrigation water treatment with the AC filter, 5 ) inoculated irrigation water treatment with the fungicide (etridiazole) application in the absence of any filters, and 6) diseased plant treatment in the absence of any filters. In Treatment 5, the etridiazole (Terrazole $35 \mathrm{WP}$ ) was applied at the labeled rate $\left(250 \mathrm{mg} \cdot \mathrm{L}^{-1}\right)$ into the irrigation water in the holding tank before the first inoculation so that all inoculated Pythium zoospores had similar fungicide exposure. In the diseased plant treatment (Treatment 6), three of the 15 planting pots were directly inoculated with the $P$. aphanidermatum zoospores and then placed randomly in Expt. 1 and at the back location near the drainage hole of the bench in Expt. 2, as shown in Supplemental Fig. 1. The encysted zoospore suspension $(50 \mathrm{~mL})$ was added to a 4 -cm-deep depression in the potting mix $2 \mathrm{~cm}$ from the stem of the healthy plant. The pots were removed from the bench during inoculation to avoid contamination of the bench and then replaced on the bench after inoculation. This treatment was designed to assess whether the pathogen could spread among the plants if not directly introduced into the irrigation water. The poinsettia plants were irrigated twice per day at 0900 and $1500 \mathrm{~h}$. Expt. 1 was initiated on 29 Oct. 2014 and concluded on 6 Jan. 2015 (69 d in duration). Expt. 2 was initiated on 2 Apr. 2015 and concluded on 19 June 2015 (78 d in duration). The initiation day was considered to be that of the first inoculation. Due to light contamination from external streetlights at night, the plants in Expt. 1 experienced an interruption of the dark period that is required to initiate flowering. Thus, in Expt. 2, the plants were covered with a thick black cloth at night to allow for flower initiation. The water pressure inside the filter unit was monitored in real time, along with the water temperature in the holding tank, and air temperature and relative humidity in the greenhouse. The irrigation water was sampled from the holding tanks at the beginning, middle, and end of each experiment to determine $\mathrm{pH}$, electrical conductivity (EC), and nutrient concentrations. After the $\mathrm{pH}$ and EC measurements, water samples were filtered through a $0.45-\mu \mathrm{m}$ membrane filter and stored in a $-20{ }^{\circ} \mathrm{C}$ freezer for later nutrients analyses by the MSU Soil and Plant Nutrient Laboratory (East Lansing).

The mean $( \pm$ SD) air temperature and relative humidity were $26.8 \pm$ $2.9{ }^{\circ} \mathrm{C}$ and $30 \% \pm 7.4 \%$ in Expt. 1 , and $26.1 \pm 3.3{ }^{\circ} \mathrm{C}$ and $36 \% \pm 16.7 \%$ in Expt. 2, respectively (Supplemental Fig. 2). The mean Darcy water velocities through the AC and sand filters were $19.6 \pm 0.5$ and $10.5 \pm 2.2$ $\mathrm{cm} \cdot \mathrm{min}^{-1}$ in Expt. 1 , and $18.6 \pm 1.3$ and $8.6 \pm 1.0 \mathrm{~cm} \cdot \mathrm{min}^{-1}$ in Expt. 2, respectively. The mean Darcy water velocities were calculated based on 3 - $d$ averages at the beginning of each experiment $(n=6)$. Thus, the two experiments had consistent water velocities through the filters. Operating water pressure of the $\mathrm{AC}$ and sand filters were maintained at $6.9 \pm 1.4$ and $5.7 \pm 1.0 \mathrm{kPa}$, respectively (Supplemental Fig. 3). Because filtration systems with a mean water velocity of 8.3 to $25 \mathrm{~cm} \cdot \mathrm{min}^{-1}$ are classified as rapid sand filtration (Gadgil, 1998; Huisman and Wood, 1974; World Health Organization, 1996), relative to slow sand filtration (0.17-0.5 $\left.\mathrm{cm} \cdot \mathrm{min}^{-1}\right)$, these filtration systems are classified as rapid filtration (8.6$\left.19.6 \mathrm{~cm} \cdot \mathrm{min}^{-1}\right)$ and low pressure.

The $\mathrm{pH}$ and $\mathrm{EC}$ of the irrigation water were $7.8 \pm 0.4$ and $1.6 \pm 0.3$ $\mathrm{mS} \cdot \mathrm{cm}^{-1}$, respectively, during the experimental periods (Supplemental Figs. 4 and 5); water temperature was in the range typical for a greenhouse (Supplemental Fig. 6). The concentrations of macronutrients, [i.e., nitrate $\left(\mathrm{NO}_{3}{ }^{-}\right)$, phosphorus $(\mathrm{P})$, potassium $(\mathrm{K})$, calcium $(\mathrm{Ca})$, magnesium $(\mathrm{Mg})$, and sodium $(\mathrm{Na})]$ in the irrigation water are shown in Supplemental Table 1. The nutrient levels (i.e., $\mathrm{NO}_{3}{ }^{-}, \mathrm{P}, \mathrm{K}, \mathrm{Ca}$, and $\mathrm{Mg}$ ) in the AC filter treatment were generally lower than those of other treatments, although the difference was less in Expt. 2. The micronutrients [i.e., iron (Fe), copper $(\mathrm{Cu})$, and zinc $(\mathrm{Zn})]$ were completely removed from the recycled irrigation water in the $\mathrm{AC}$ filter treatment (Supplemental Fig. 7).

Due to the limitation in the number of constructed irrigation systems and the greenhouse space, we could not include multiple irrigation systems for each treatment in the two greenhouse experiments. However, the sufficient number of poinsettia plants in each treatment ( 15 plants) allowed for reliable assessment of plant responses to treatment. The two experiments were not exactly replicated due to slightly varied air temperature and relative humidity in the greenhouse and the interruption of dark period in Expt. 1 as described earlier. Nonetheless, these two experiments could still ensure the reliability of our conclusions especially if they were drawn from the results obtained under varied experimental conditions.

Plant assessments. To assess the performance of the filtration systems in controlling pythium root rot outbreaks, the poinsettia plants were evaluated at the end of the experiments for foliar and root weight, root rot severity, and horticultural quality. The roots were visually examined for root necrosis in 15 plant pots using a scale adapted from Boehm and Hoitink (1992) where 1 = no symptoms; 2 = mild root rot, less than onethird of plant roots affected; $3=$ intermediate root rot, one-third to two-thirds of plant roots affected; $4=$ severe root rot, more than twothirds of plant roots affected; $5=$ severe root and crown rot; and $6=$ dead plant. This rating was made without removing the potting mix from the roots. In Expt. 2, the plants were rated for their horticultural quality (Ecke et al., 2004) based on the appearance (e.g., color, height, and bract area) on the scale from 1 (high aesthetic quality) to 5 (no aesthetic quality) (Supplemental Fig. 8). At harvest, the roots were carefully washed, and the fresh weight of the poinsettia shoots and roots were measured. The shoot and root samples were then oven-dried at $60{ }^{\circ} \mathrm{C}$ for $3 \mathrm{~d}$ 
and measured for their dry weight. Isolation of $P$. aphanidermatum from the roots of each plant was attempted. The roots were rinsed gently under running tap water to remove any adhering potting mixture. Three water-soaked or discolored roots were selected per plant and were surfacesterilized in $70 \%$ ethanol, blotted dry, and plated onto BARP ( $50 \mathrm{ppm}$ benomyl, $100 \mathrm{ppm}$ ampicillin, $30 \mathrm{ppm}$ rifampicin, and 200 ppm pentachloronitrobenzene)-amended CMA, and incubated at $30{ }^{\circ} \mathrm{C}$ for $24 \mathrm{~h}$. A percentage of colonies were transferred to CMA and confirmed as $P$. aphanidermatum based on sporangial and oospore morphology as well as colony appearance using the key of van der Plaats-Niterink (1981). The number of plants with the presence of $P$. aphanidermatum was divided by the total number of plants $(\mathrm{n}=15)$ to determine the root infection ratio.

Chlorophyll $\mathrm{a}$ and $\mathrm{b}$ concentrations in the poinsettia leaves were measured using a colorimetric method (Wellburn, 1994). Three poinsettia plants were randomly selected, and $0.5 \mathrm{~g}$ of the leaf sample was collected from more than three leaves in the middle part of each plant. The fresh leaf samples were processed immediately after collection. The weighed leaf samples were homogenized with the addition of $10 \mathrm{~mL}$ of $80 \%$ acetone. The extract was centrifuged at $2500 \mathrm{rpm}$ for $5 \mathrm{~min}$, and the supernatant was diluted 10 times by adding $80 \%$ acetone. The final extracted solution was analyzed for the chlorophyll concentrations by a spectrophotometer (Varian Cary 50 Bio; Agilent Technologies, Santa Clara, CA). To analyze the macroand micronutrients [i.e., $\mathrm{N}$, sulfur (S), $\mathrm{Mg}, \mathrm{Ca}, \mathrm{Na}$, boron (B), $\mathrm{Zn}$, manganese $(\mathrm{Mn}), \mathrm{Fe}, \mathrm{Cu}$, and aluminum $(\mathrm{Al})]$ in the poinsettia leaves, the stems were removed and the remaining leaf tissues were ground before being analyzed at the A \& L Great Lakes Laboratories, Inc. (Fort Wayne, IN) following the standard methods of the Association of Official Analytical Chemists.

Statistical analyses. Statistical analyses of the experimental data were performed with $\mathrm{R}$ software using the least significant difference (LSD) $R$ package for parametric tests and the "coin" R package for a nonparametric test such as the rating data (i.e., the ratings of root rot severity and horticultural quality). Treatments were compared by one-way analysis of variance $(P \leq 0.05)$. When a significant $F$ value was determined, means were separated by the LSD's multiple comparison test. Also, the Student's $t$ test was used to compare paired samples. Data of preinoculated plants in the diseased plant treatment were not included in the statistical analyses. To compare nonparametric data, such as root rot severity and horticulture quality, the Kruskal-Wallis test was used with the "coin" $\mathrm{R}$ package. Its statistical significance probability value was adjusted $(P \leq 0.034)$ by Bonferroni correction to reduce the risk of committing Type I errors for multiple comparison.

\section{Results}

Poinsettia plants in the sand filter treatment consistently showed healthy roots similar to those of the noninoculated control, demonstrating the effectiveness of rapid sand filtration in limiting Pythium infection. In Expt. 1, the level of root necrosis in the inoculated control plants was significantly $(P<0.004)$ more than that of the noninoculated control, sand filter, AC filter, and diseased plant treatments (Table 1 ). Root necrosis in the etridiazole

Table 1. Ratings of root rot severity and horticultural quality of poinsettia plants in Expts. 1 and $2(n=15) .^{\mathrm{z}}$

\begin{tabular}{|c|c|c|c|}
\hline \multirow[b]{3}{*}{ Treatment $^{\mathrm{z}}$} & Expt. $1^{y}$ & \multicolumn{2}{|c|}{ Expt. $2^{y}$} \\
\hline & $\overline{\text { Root rot severity }}$ & Root rot severity & Horticultural quality \\
\hline & \multicolumn{2}{|c|}{$[\text { mean } \pm \text { sD }(1-6 \text { scale })]^{x}$} & {$[\text { mean } \pm \text { sD }(1-5 \text { scale })]^{\mathrm{w}}$} \\
\hline -Control & $1.7 \pm 1.0 \mathrm{a}^{\mathrm{v}}$ & $1.1 \pm 0.4 \mathrm{a}^{\mathrm{v}}$ & $1.4 \pm 0.6 \mathrm{a}^{\mathrm{v}}$ \\
\hline +Control & $3.8 \pm 1.0 \mathrm{~b}$ & $3.2 \pm 0.9 b$ & $3.0 \pm 0.8 b$ \\
\hline AC filter & $1.4 \pm 0.5 \mathrm{a}$ & $3.2 \pm 0.6 b$ & $4.7 \pm 0.5 \mathrm{c}$ \\
\hline Sand filter & $1.7 \pm 0.9 \mathrm{a}$ & $1.2 \pm 0.4 \mathrm{a}$ & $1.7 \pm 0.5 \mathrm{a}$ \\
\hline Diseased plant & $1.8 \pm 1.1 \mathrm{a}$ & $1.5 \pm 1.2 \mathrm{a}$ & $2.3 \pm 0.8 \mathrm{ab}$ \\
\hline Etridiazole & $2.5 \pm 1.2 \mathrm{ab}$ & $3.0 \pm 0.7 \mathrm{~b}$ & $1.9 \pm 0.6 \mathrm{a}$ \\
\hline
\end{tabular}

${ }^{z}$-Control $=$ noninoculated irrigation water treatment without filtration or pathogen; +Control $=$ inoculated irrigation water treatment without filtration or fungicide; AC filter = inoculated irrigation water treatment with the activated carbon filter; Sand filter = inoculated irrigation water treatment with the sand filter; Diseased plant = diseased plant treatment in the absence of any filters; Etridiazole = inoculated irrigation water treatment with the fungicide (etridiazole) application in the absence of any filters. In the diseased plant treatment, the infested planting pots were placed randomly in Expt. 1, but at the back location near the drainage of the bench in Expt. 2 .

${ }^{y}$ Expts. 1 and 2 were performed to assess the effectiveness of rapid filtration and fungicide application to control pythium root rot of poinsettia in greenhouse. Irrigation water in constructed ebb-and-flow recirculating irrigation systems was inoculated with encysted Pythium aphanidermatum zoospores at $68 \pm 36$ zoospores $/ \mathrm{mL}(2011.0 \pm$ 1064.6 zoospores $/ \mathrm{fl} \mathrm{oz}$ ) at the initiation and then 2 and 4 weeks afterward in each experiment. Each Expt. 2 included six treatments; sand and activated filters were used to remove Pythium zoospores from infested irrigation water. Expt. 1 experienced the interruption of the dark period.

${ }^{x}$ Root rot severity was rated as per the following scale: $1=$ no symptoms; $2=$ mild root rot, less than one-third of plant roots affected; 3 = intermediate root rot, one-third to two-thirds of plant roots affected; $4=$ severe root rot, more than two-thirds of plant roots affected; $5=$ severe root and crown rot; and $6=$ dead plant.

${ }^{\text {w} H o r t i c u l t u r a l ~ q u a l i t y ~ w a s ~ r a t e d ~ a c c o r d i n g ~ t o ~ t h e ~ a p p e a r a n c e ~(e . g ., ~ c o l o r, ~ h e i g h t, ~ a n d ~ b r a c t ~ a r e a) ~ o n ~ t h e ~ s c a l e ~ f r o m ~}$ $\mathrm{l}$ (high aesthetic quality) to 5 (no aesthetic quality).

${ }^{v}$ Means within a column with different letters are significantly different based on the Kruskal-Wallis with Bonferroni corrected test $(P<0.004)$. 

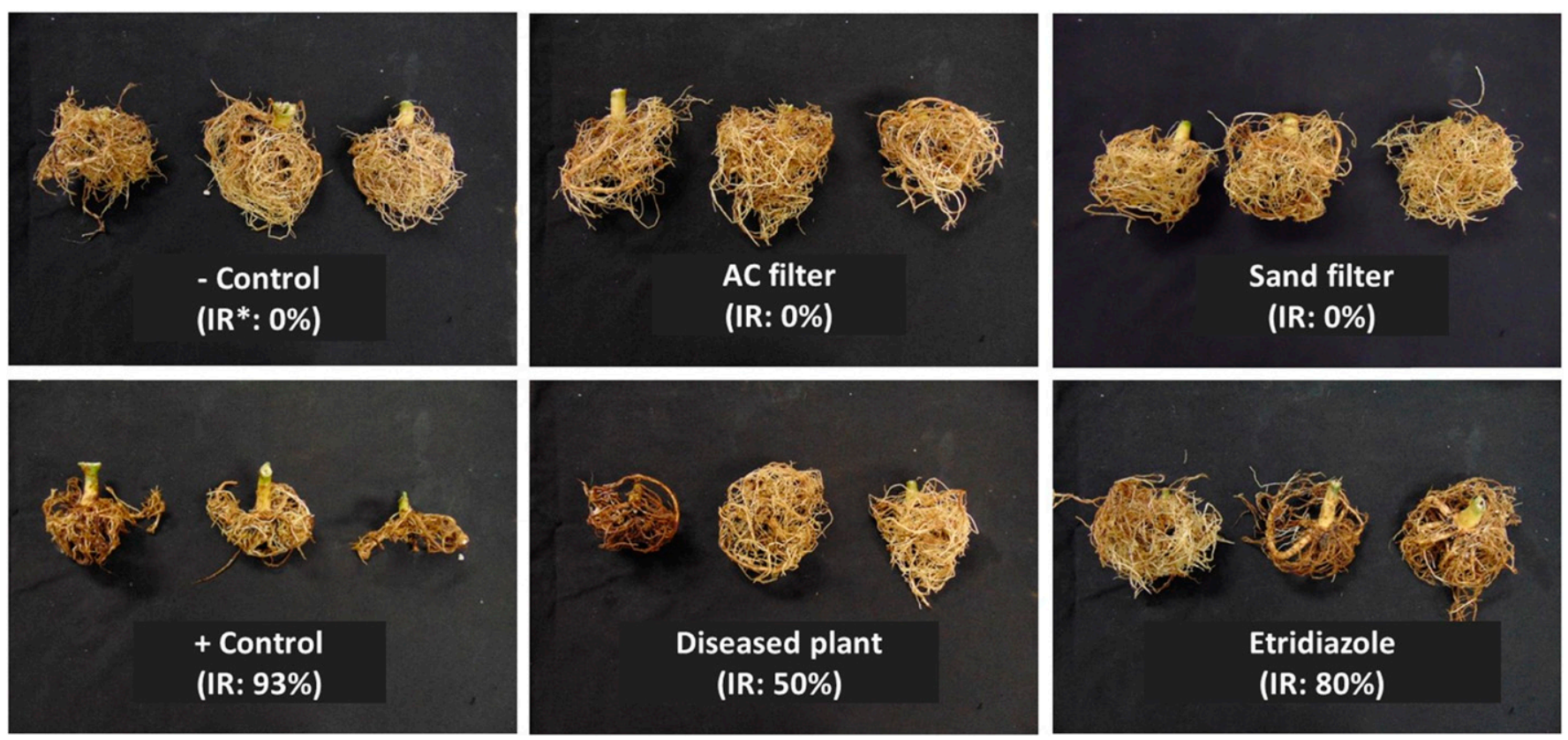

Fig. 3. Representative roots of poinsettia at the end of Expt. 1 (69 d after inoculation with Pythium aphanidermatum zoospores). Expt. 1 was performed to assess the effectiveness of rapid filtration and fungicide application to control pythium root rot of poinsettia in greenhouse, including six treatments: -Control = noninoculated irrigation water treatment without filtration or pathogen; + Control = inoculated irrigation water treatment without filtration or fungicide; Sand filter = inoculated irrigation water treatment with the sand filter; AC filter = inoculated irrigation water treatment with the activated carbon filter; Etridiazole = inoculated irrigation water treatment with the fungicide (etridiazole) application in the absence of any filters; Diseased plant $=$ diseased plant treatment in the absence of any filters. Irrigation water in constructed ebb-and-flow recirculating irrigation systems was inoculated with encysted $P$. aphanidermatum zoospores at $68 \pm 36$ zoospores $/ \mathrm{mL}(2011.0 \pm$ 1064.6 zoospores $/ \mathrm{fl} \mathrm{oz}$ ) at the initiation of Expt. 2 and then 2 and 4 weeks afterward. Sand and activated filters were used to remove $P$. aphanidermatum zoospores from infested irrigation water. In the diseased plant treatment of Expt. 1 , the infested planting pots were placed randomly. Expt. 1 experienced the interruption of the dark period. IR is the infection ratio of $P$. aphanidermatum in roots.

Expt. 2, the inoculated control plants had an inferior appearance with a horticultural quality rating of 3.0, and were not marketable (Table 1, Supplemental Fig. 10B). The plants subjected to the AC filter treatment had the poorest aesthetic quality with a horticultural rating of 4.7 , whereas the plants in the remainder of the treatments had a more similar horticultural quality [1.4-2.3 (Table 1)].

In Expt. 1, the sand filter, etridiazole, diseased plant, and noninoculated control treatments had significantly higher plant height, foliar fresh weight, and root dry weight than those of the inoculated control plants $[P<0.05$ (Fig. 4)]. However, plants in the AC filter treatment had significantly lower fresh foliar weight and root dry weight than those of the noninoculated control $[P<0.05$ (Fig. 4)]. In Expt. 2, the sand filter, etridiazole, diseased plant, and noninoculated control treatments had significantly higher plant height, and foliar fresh and dry weight than those of the inoculated control and AC filter treatment $[(P<0.05$ (Fig. 5)].

Chlorosis of young leaves was observed for plants in the AC filter treatment in both experiments (Supplemental Fig. 11). Chlorophyll a and b concentrations for the mediumsized leaves after harvest were significantly lower in the AC filter treatment than those of other treatments (Table 2 ). The leaves had higher levels of $S$ and $\mathrm{Ca}$ and lower levels of $\mathrm{B}, \mathrm{Zn}, \mathrm{Fe}$, and $\mathrm{Cu}$ in the $\mathrm{AC}$ filter treatment, relative to the noninoculated control (Table 3). There was no significant difference in the concentrations of $\mathrm{N}, \mathrm{P}, \mathrm{K}, \mathrm{Mg}, \mathrm{Na}, \mathrm{Mn}$, and $\mathrm{Al}$ in the leaves from the AC filter treatment and the noninoculated control treatments (Table 3).

\section{Discussion}

Our results demonstrated that poinsettia plants under rapid sand filtration were consistently similar to the non-inoculated control, regarding the presence of $P$. aphanidermatum, root necrosis, plant height and weight, and horticultural quality (Table 1, Figs. 3-5, Supplemental Fig. 10). Thus, rapid sand filtration effectively limited pythium root rot and maintained poinsettia plant quality, likely by removing $P$. aphanidermatum zoospores from the irrigation water. Many laboratory and greenhouse experiments have consistently shown that sand filters can effectively remove pythiaceous zoospores from water (Déniel et al., 2004; Jeon et al., 2016; Lee and Oki, 2013; Ufer et al., 2008; van Os et al., 1998; Vankuik, 1994). Similar results have also been found with slow sand filtration under experimental conditions (Darling, 1977; Déniel et al., 2004; Lee and Oki, 2013; van Os et al., 1998, 2000). The slow sand filtration was initially developed for wastewater treatment through biological processes; a biological layer termed Schmutzdecke is the most critical factor for purification (Huisman and Wood, 1974). However, others suggested that the main mechanisms to remove pythiaceous zoospores 

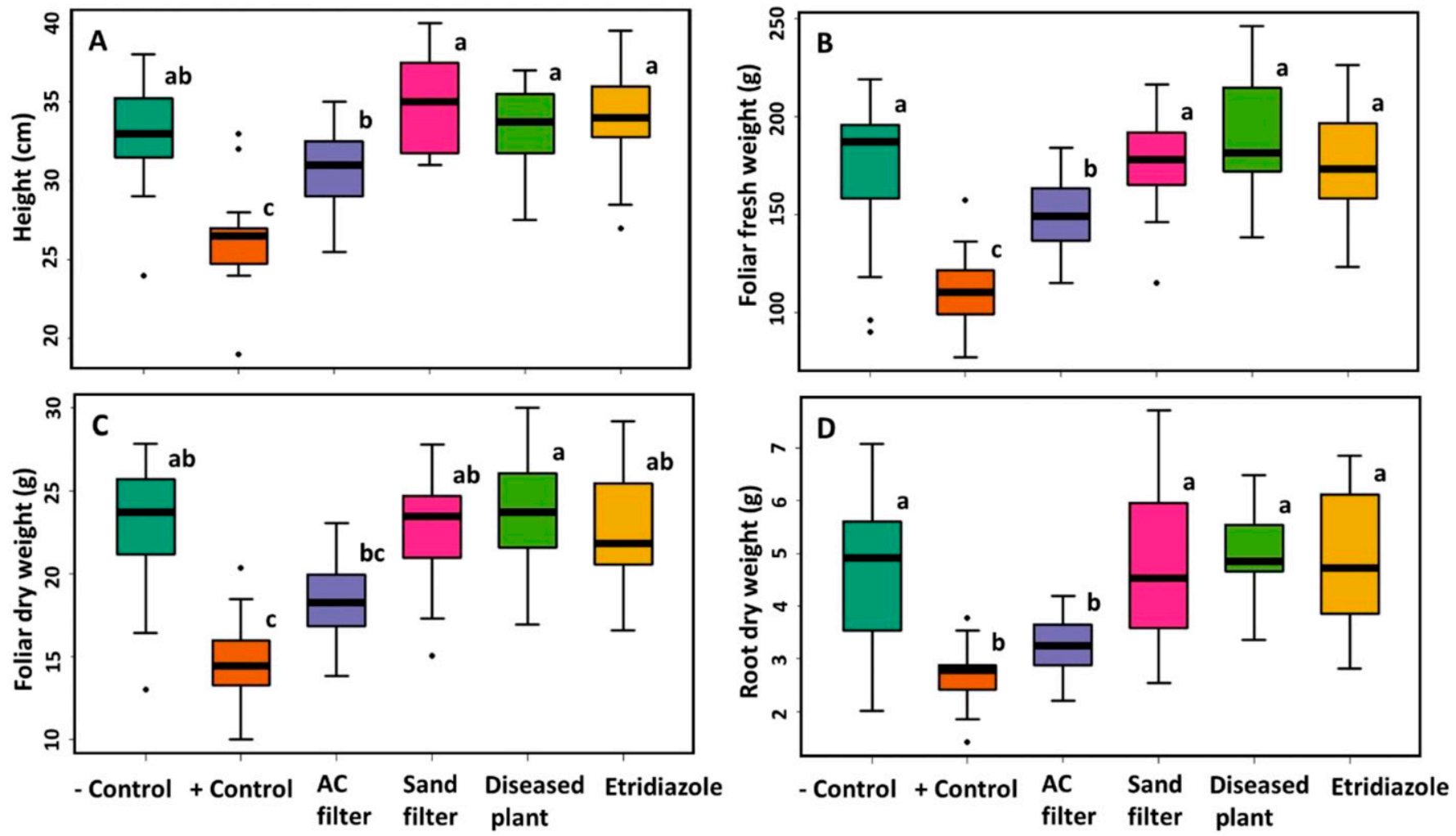

Fig. 4. Poinsettia height (A), foliar fresh weight (B), foliar dry weight (C), and root dry weight (D) in Expt. 1. Expt. 1 was performed to assess the effectiveness of rapid filtration and fungicide application to control pythium root rot of poinsettia in greenhouse, including six treatments: - Control = noninoculated irrigation water treatment without filtration or pathogen; + Control $=$ inoculated irrigation water treatment without filtration or fungicide; Sand filter $=$ inoculated irrigation water treatment with the sand filter; AC filter = inoculated irrigation water treatment with the activated carbon filter; Etridiazole = inoculated irrigation water treatment with the fungicide (etridiazole) application in the absence of any filters; Diseased plant = diseased plant treatment in the absence of any filters. Irrigation water in constructed ebb-and-flow recirculating irrigation systems was inoculated with encysted Pythium aphanidermatum zoospores at $68 \pm 36$ zoospores $/ \mathrm{mL}(2011.0 \pm 1064.6$ zoospores $/ \mathrm{fl} \mathrm{oz}$ ) at the initiation of Expt. 2 and then 2 and 4 weeks afterward. Sand and activated filters were used to remove $P$. aphanidermatum zoospores from infested irrigation water. In the diseased plant treatment of Expt. 1, the infested planting pots were placed randomly. Expt. 1 experienced the interruption of the dark period. The different lower case letters above columns indicate the significant difference in means at $P<0.05$ by least significant difference test; $1 \mathrm{~cm}=0.3937 \mathrm{inch}, 1 \mathrm{~g}=$ $0.0353 \mathrm{oz}$.

primarily include surface attachment, pore straining, and adhesive interactions of the zoospores in porous media (Déniel et al., 2004; Jeon et al., 2016; van Os et al., 1998, 2000 ). Thus, the physicochemically controlled rapid filtration can be a viable alternative for treating recycled irrigation water in the greenhouse. Slow sand filtration is often not suitable for greenhouse production due to its low water flow rate and the large area required for the filtration system (Wohanka and Helle, 1996). In this study, the flow velocity of the rapid sand filter was $\approx 40-50$ times that in typical slow sand filters and would thus meet the water demand in commercial greenhouses with a small installation area.

In the AC filter treatment there was no presence of P. aphanidermatum zoospores (Fig. 3). However, the plant weight and height under the AC filter treatment were, in general, significantly reduced compared with the noninoculated and sand filter treatments (Figs. 4 and 5). Because $P$. aphanidermatum was not detected in the relatively healthy-appearing roots in the AC filter treatment of Expt. 1 (Fig. 3), the leaf chlorosis and stunted growth may have resulted from abiotic factors. As the $\mathrm{AC}$ removed essential micronutrients (e.g., $\mathrm{Fe}, \mathrm{Cu}, \mathrm{Mn}$, and $\mathrm{Zn}$ ) from the irrigation water (Supplemental Fig. 7), and the concentrations of $\mathrm{Fe}, \mathrm{Cu}$, and $\mathrm{B}$ in the plant leaves (Table 3 ) were in the deficient range (Campbell, 2000), leaf chlorosis was likely a result of micronutrient deficiency. The chlorosis of young leaves indicates Fe deficiency
(Hochmuth et al., 2004; McCauley et al., 2009). Similarly, kiwifruit (Actinidia sp.) showed the $\mathrm{Fe}$ deficiency symptoms when a soil was amended with a wood-based biochar (Sorrenti et al., 2016), a carbon-rich porous media sharing some similar properties to those of the AC (Chen et al., 2011; Hale et al., 2011). Additionally, interplays between the nutrient absorption by poinsettia roots and nutrient removal by the AC filter were also observed. Nutrient deficiency in Expt. 2 may have caused severe root necrosis for plants in the AC filter treatment, which might in turn result in insufficient macronutrient absorption and subsequently higher nutrient levels in irrigation water than those in Expt. 1. In general, the removal of nutrients by the AC may prevent its adoption for water 

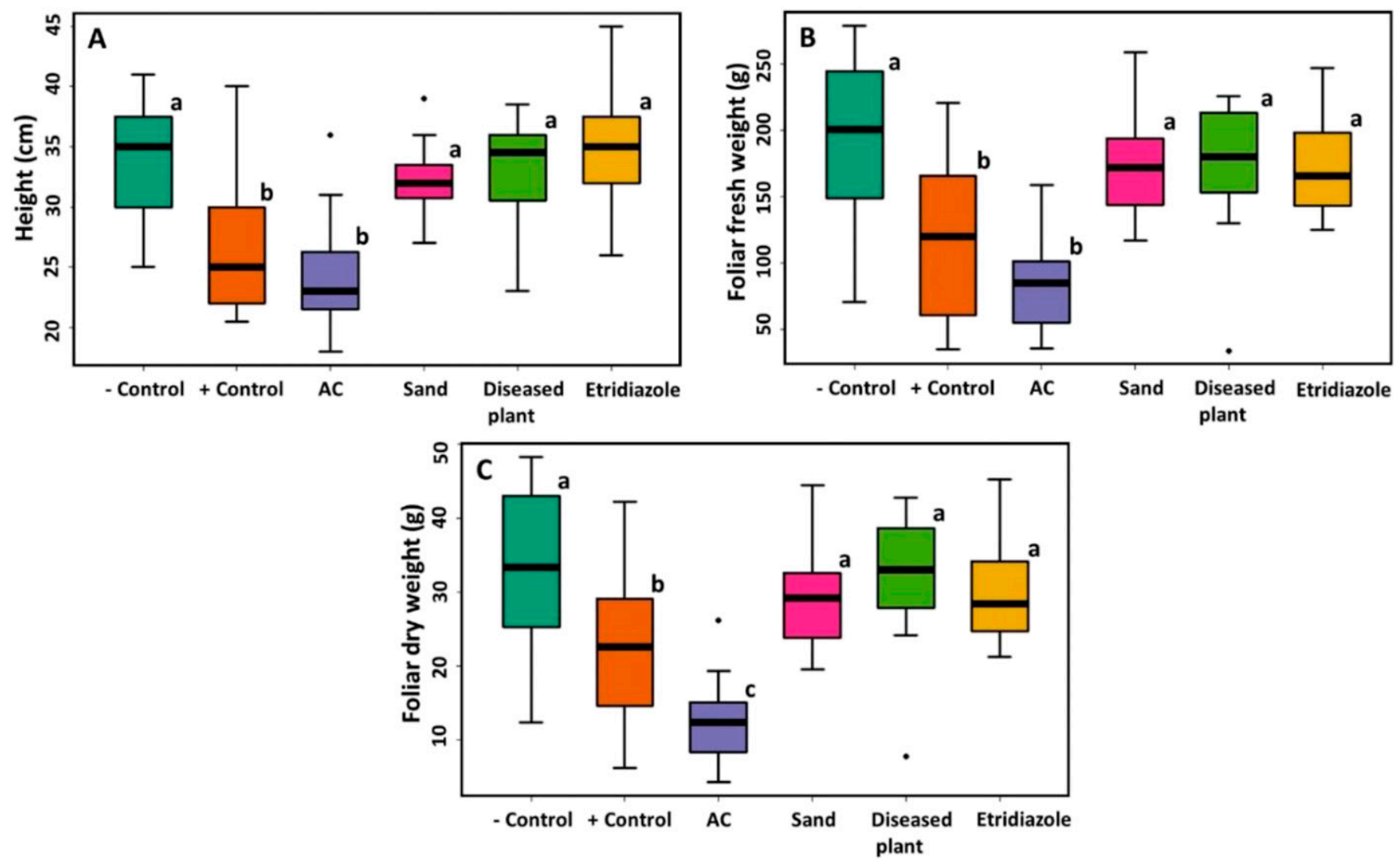

Figure 5. Poinsettia height (A), foliar fresh weight (B), and foliar dry weight (C) in Expt. 2. Expt. 2 was performed to assess the effectiveness of rapid filtration and fungicide application to control pythium root rot of poinsettia in greenhouse, including six treatments: - Control $=$ non-inoculated irrigation water treatment without filtration or pathogen; + Control $=$ inoculated irrigation water treatment without filtration or fungicide; Sand = inoculated irrigation water treatment with the sand filter; $\mathrm{AC}=$ inoculated irrigation water treatment with the activated carbon filter; Etridiazole $=$ inoculated irrigation water treatment with the fungicide (etridiazole) application in the absence of any filters; Diseased plant = diseased plant treatment in the absence of any filters. Irrigation water in constructed ebb-and-flow recirculating irrigation systems was inoculated with encysted Pythium aphanidermatum zoospores at $68 \pm 36$ zoospores $/ \mathrm{mL}(2011.0 \pm 1064.6$ zoospores/fl oz $)$ at the initiation of Expt. 2 and then 2 and 4 weeks afterward. Sand and activated filters were used to remove $P$. aphanidermatum zoospores from infested irrigation water. In the diseased plant treatment of Expt. 2, the infested planting pots were placed at the back location near the drainage of the bench. The different lower case letters above columns indicate the significant difference in means at $P<0.05$ by least significant difference test; $1 \mathrm{~cm}=0.3937 \mathrm{inch}, 1 \mathrm{~g}=0.0353 \mathrm{oz}$.

treatments in commercial greenhouses (Runia, 1993). Despite its effectiveness in controlling plant pathogens, AC filters would be impractical for commercial poinsettia production due to poor plant quality and nutrient deficiency, unless fertilizers could be properly applied through means other than fertigation in irrigation water.

In the etridiazole treatment across both experiments, poinsettias had similar weight and height to those in the noninoculated control (Figs. 4 and 5). However, root infection was not prevented by fungicide application. P. aphanidermatum was isolated from roots exhibiting an intermediate level of root rot severity in Expt. 1 (Fig. 3; Table 1). In Expt. 2 , the plant roots also displayed an intermediate level of root rot severity (Table 1), but no P. aphanidermatum was isolated, probably due to a low level of $P$. aphanidermatum near the detection limit of the isolation method. In a previous study using the ebb-and-flood system, when etridiazole was incorporated into the growing medium, necrosis was reduced at the stem base of cucumbers (Cucumis sativus), whereas P. aphanidermatum recovery from roots was not decreased (Sanogo and Moorman, 1993). In another study using a hydroponic system, etridiazole applied in the recirculating irrigation water reduced root rot of ivy (Hedera sp.) but not as effectively as the fungicide mefenoxam (Jamart et al., 1988). Thus, the rate of etridiazole in the irrigation water may not be adequate in controlling infection, due to the presence of $P$. aphanidermatum in the poinsettia roots in Expt. 1. The labeled rate of etridiazole did not cause $100 \%$ mortality to zoospores of sensitive isolates of $P$. aphanidermatum in vitro (Krasnow and Hausbeck, 2017). Additionally, application of sublethal doses of fungicides may influence sensitivity of Pythium species to fungicides and exacerbate disease symptoms (Garzón et al., 2011). Plants may not be adequately protected if the fungicide concentration is below the threshold necessary to prevent disease. Symptoms of root rot occurred with etridiazole-treated water in the absence of $P$. aphanidermatum in Expt. 2 (Supplemental Fig. 9B), suggesting that the recommended dosage of this 
Table 2. Chlorophyll a and b concentrations in leaves of greenhouse poinsettia in Expts. 1 and 2.

\begin{tabular}{|c|c|c|c|c|}
\hline \multirow[b]{2}{*}{ Treatments $^{\mathrm{z}}$} & \multicolumn{2}{|c|}{ Expt. $1^{y}$} & \multicolumn{2}{|c|}{ Expt. $2^{y}$} \\
\hline & Chlorophyll a $\left(\mathrm{mg} \cdot \mathrm{kg}^{-1}\right)^{\mathrm{x}}$ & Chlorophyll b (mg.kg $\left.{ }^{-1}\right)$ & Chlorophyll a (mg.kg $\left.{ }^{-1}\right)$ & Chlorophyll b $\left(\mathrm{mg} \cdot \mathrm{kg}^{-1}\right)$ \\
\hline -Control & $854 b^{w}$ & $1526 \mathrm{bc}$ & $324 \mathrm{ab}$ & $2208 \mathrm{ab}$ \\
\hline AC filter & $330 \mathrm{~d}$ & $520 \mathrm{~d}$ & $81 \mathrm{~d}$ & $508 \mathrm{~d}$ \\
\hline Sand filter & $783 \mathrm{c}$ & $1361 \mathrm{c}$ & $260 \mathrm{c}$ & $1772 \mathrm{c}$ \\
\hline Diseased plant & 959 a & $1613 \mathrm{~b}$ & $302 \mathrm{abc}$ & $2037 \mathrm{abc}$ \\
\hline
\end{tabular}

${ }^{z}$-Control = noninoculated irrigation water treatment without filtration or pathogen; +Control = inoculated irrigation water treatment without filtration or fungicide; AC filter $=$ inoculated irrigation water treatment with the activated carbon filter; Sand filter $=$ inoculated irrigation water treatment with the sand filter; Diseased plant $=$ diseased plant treatment in the absence of any filters; Etridiazole = inoculated irrigation water treatment with the fungicide (etridiazole) application in the absence of any filters. In the diseased plant treatment, the infested planting pots were placed randomly in Expt. 1, but at the back location near the drainage of the bench in Expt. 2 .

${ }^{y}$ Expts. 1 and 2 were performed to assess the effectiveness of rapid filtration and fungicide application to control pythium root rot of poinsettia in greenhouse. Irrigation water in constructed ebb-and-flow recirculating irrigation systems was inoculated with encysted Pythium aphanidermatum zoospores at $68 \pm 36$ zoospores $/ \mathrm{mL}$ ( $2011.0 \pm 1064.6$ zoospores $/ \mathrm{fl} \mathrm{oz}$ ) at the initiation and then 2 and 4 weeks afterward in each experiment. Each Expt. 2 included six treatments; sand and activated filters were used to remove Pythium zoospores from infested irrigation water. Expt. l experienced the interruption of the dark period.

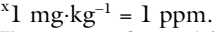

${ }^{\text {w }}$ Least significant difference test was performed and different letters within a column indicate a significant difference in means at $P<0.05$.

Table 3. Macro- and micronutrients in the leaves of poinsettia in activated carbon filter and negative control treatments of Expt. $2(n=3){ }^{z}$

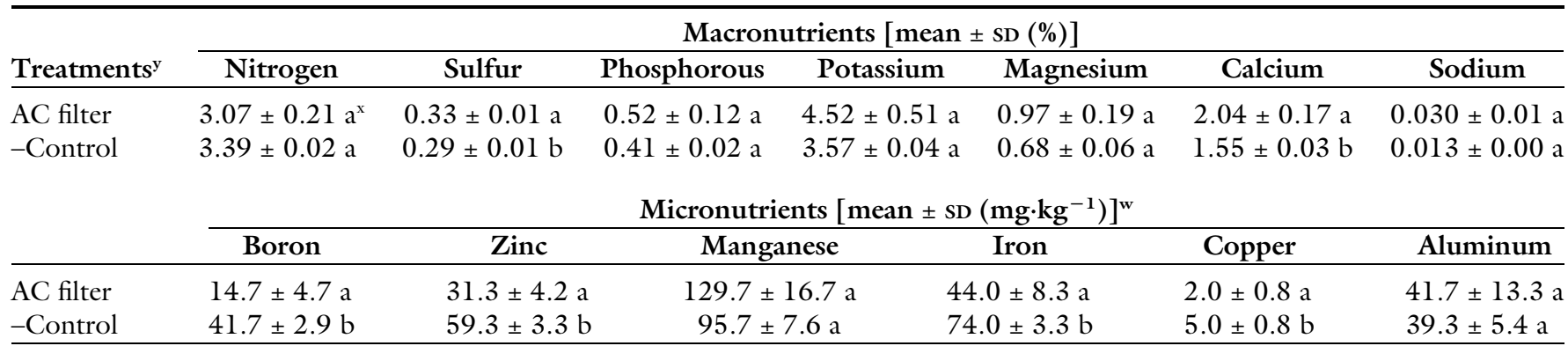

${ }^{\mathrm{z}}$ Expt. 2 was performed to assess the effectiveness of rapid filtration and fungicide application to control pythium root rot of poinsettia in greenhouse. Irrigation water in constructed ebb-and-flow recirculating irrigation systems was inoculated with encysted Pythium aphanidermatum zoospores at $68 \pm 36$ zoospores $/ \mathrm{mL}(2011.0 \pm 1064.6$ zoospores/fl oz) at the initiation of Expt. 2 and then 2 and 4 weeks afterward.

$\mathrm{y}_{\text {-Control }}$ noninoculated irrigation water treatment without filtration or pathogen; AC filter $=$ inoculated irrigation water treatment with the activated carbon filter used to remove Pythium zoospores from irrigation water.

${ }^{\mathrm{x}}$ Student's $t$ test, and different letters in the same column indicate a significant difference at $P<0.05$.

${ }^{\mathrm{w}} \mathrm{l} \mathrm{mg} \cdot \mathrm{kg}^{-1}=\mathrm{l} \mathrm{ppm}$.

fungicide may cause phytotoxicity in roots that resemble root rot symptoms (Dumroese et al., 1990). Future studies are needed to confirm the observations in this proof-of-concept study and to further explore underlying mechanisms.

To demonstrate pathogen transmission from growth media to plant, we randomly placed three infested pots among 12 healthy plant pots. In Expt. 1, P. aphanidermatum from infested pots was transferred to healthy plants (Fig. 3). The infection did not result in a significant difference in the average root rot severity or plant height and weight (Table 1; Fig. 4), likely due to low migration of zoospores from inoculated pots to irrigation water, limited sporangial and zoospore production from infected plants, or the masking effect from other healthy plants (Supplemental Fig. 1). Some of the infected plants exhibited root rot symptoms by the end of the experiment (Supplemental Fig. 9A). Transmission of $P$. aphanidermatum from infested growth media to healthy plants appeared less efficient than infesting the irrigation water, and has been observed by other researchers (Stanghellini et al., 1996b). The pathogen did not spread to healthy plants when infested pots were placed at the back near the drain (Supplemental Fig. 1A). It is possible that the released zoospores from the infected roots could be drained away with the irrigation water, and then become attached to the surfaces of pipes and walls during encystment (Gubler et al., 1989). It is unlikely that the zoospores would be transported against the flow direction. Thus, zoospores were possibly transported by irrigation water to infect the plants in Expt. 1, as the infested plants were located along the flow direction in the middle of the bench (Supplemental Fig. 1). Future studies should be directed to explore the effectiveness of control practices such as filtration and fungicide application for preventing Pythium diseases of plants when inoculum is applied to growing media and plants rather than to irrigation water.

It was noted that after $\approx 1$ month from the start of Expt. 2, a significant water flow reduction was observed in the sand filter treatment over time, likely due to clogging of the sand filter by debris or biofilm (Vankuik, 1994). The clogging can usually be remediated easily by backwash that is often performed in typical filtration operations ( $\mathrm{Tu}$ and Harwood, 2005). Recently, Kim et al. (2015) reported that a pungent oil of fresh ginger (Zingiber officinale), 6 gingerol, reduced Psendomonas aeruginosa 
biofilm formation up to $53 \%$ by inhibiting quorum sensing-regulated virulence behaviors. In addition, several quorum-sensing inhibitors including RNAIII-inhibiting peptide, usnic acid, and a natural secondary metabolite of lichen could also inhibit biofilm formation (Algburi et al., 2017). However, no study has been conducted on whether the quorum sensing inhibitors can maintain the water flow rate in a sand filter. Thus, to maintain the proper water flow rate, backwash was conducted once per week after 1 month and then every other day during the last 3 weeks of Expt. 2. No significant reduction of water flow rate was found in Expt. 1, so backwash was only performed two times during the final month of the experiment. Because performing the backwash sustained the desired water flow rate in our sand filters, using rapid sand filtration may be an option to limit Pythium species in recycled irrigation water in commercial greenhouses due to its low cost to install, maintain, and operate (Ehret et al., 2001). It is possible that some of the filtered zoospores would be flushed out to the prefilter tank and then filtered again in subsequent filtration events. Alternatively, backwash water could be bypassed and collected separately for disposal.

\section{Conclusion}

The findings of this study had several important implications for controlling Pythium diseases in greenhouse floriculture crops. The infection and disease symptoms in poinsettia plants by $P$. aphanidermatum were effectively controlled by the sand and AC filters during rapid filtration with low water pressure. Rapid sand filtration maintained poinsettia quality comparable to that of the noninoculated control. However, the AC filter removed essential nutrients from the irrigation water and caused Fe deficiency symptoms in poinsettia plants. Thus, rapid sand filtration could be a viable option for minimizing Pythium outbreaks through recycled irrigation water, whereas the use of rapid AC filtration for recirculating irrigation systems seems to be impractical, unless nutrients can be applied separately other than through irrigation water. The application of etridiazole did not completely prevent Pythium infection (e.g., root rots), but plant quality in terms of weight, height, and horticultural quality was not compromised. Hence, etridiazole application is still useful to control Pythium outbreaks, but proper application rate of etridiazole needs to be studied to avoid potential phytotoxicity. When poinsettia plants were randomly infected by $P$. aphanidermatum, the pathogen spread among plants in the absence of any treatment, suggesting the need of proactive measures to control pathogen transmission either by fungicide application or filtration, which warrants further studies. As a proof-ofconcept study, the present work was limited in scope regarding the number of replications, operation conditions, and pathogen exposure scenarios. Future work should focus on more replications under realistic field conditions and on assessing the longevity of the system performance by optimizing filter media and operation parameters (e.g., water velocity and chemistry). For instance, filter design can be improved by incorporating anticlogging mechanisms such as a deeper coarse layer at the inlet or a removable screen for dislodging accumulated debris. Sand grain size could also be optimized to improve water flow while maintaining the zoospore removal efficiency. Finally, irrigation frequency and duration and backwash scheduling may be optimized to ensure continuous performance of the filtration system. Overall, this study suggests that rapid sand filtration of irrigation water can effectively reduce crop disease outbreaks in greenhouses, thus potentially lowering use of fungicides and promoting crop and environmental health.

\section{Literature cited}

Algburi, A., N. Comito, D. Kashtanov, L.M.T. Dicks, and M.L. Chikindas. 2017. Control of biofilm formation: Antibiotics and beyond. Appl. Environ. Microbiol. 83(3):e02508-e02516.

Ascerno, M.E., F. Pfleger, and H.F. Wilkins. 1981. Effect of root rot and Rhizoglyphus robini on greenhouseforced easter lily development. Environ. Entomol. 10(6):947-949.

Boehm, M. and H. Hoitink. 1992. Sustenance of microbial activity in potting mixes and its impact on severity of pythium root rot of poinsettia. Phytopathology 82(3):259-264.
Bush, E.A., C. Hong, and E.L. Stromberg. 2003. Fluctuations of Phytophthora and Pythium spp. in components of a recycling irrigation system. Plant Dis. 87(12): 1500-1506.

Campbell, C.R. 2000. Poinsettia, p. 117. In: C.R. Campbell (ed.). Reference sufficiency ranges for plant analysis in the southern region of the United States. Southern Assn. Agr. Expt. Sta. Directors, Raleigh, NC.

Carlson, K., C. Hong, and P. Richardson. 2004. Characterization of fungicide resistance and pathogenic fitness in a population of Pythium dissotocum isolated from nursery irrigation water. Phytopathology 94(6):S14 (Abstr.).

Chen, X., G. Chen, L. Chen, Y. Chen, J. Lehmann, M.B. McBride, and A.G. Hay. 2011. Adsorption of copper and zinc by biochars produced from pyrolysis of hardwood and corn straw in aqueous solution. Bioresour. Technol. 102(19):88778884 .

Darling, D. 1977. A mobile filtration plant to eliminate fungal spores in irrigation water for plant propogation. Short communication. Austral. For. Res. 7:273-274.

Déniel, F., P. Rey, M. Chérif, A. Guillou, and Y. Tirilly. 2004. Indigenous bacteria with antagonistic and plant-growthpromoting activities improve slow-filtration efficiency in soilless cultivation. Can. J. Microbiol. 50(7):499-508.

Dole, J.M. and H.F. Wilkins. 2005. Floriculture: Principles and species. Pearson Educ., Upper Saddle River, NJ.

Dumroese, R., R. James, and D. Wenny. 1990. Trial of a granular etridiazole and thiophanate-methyl mixture to control Fusarium root disease of container-grown douglas-fir seedlings. New For. 4(3):231236.

Ecke, P., III, J.E. Faust, A. Higgins, and J. Williams. 2004. The Ecke poinsettia manual. Ball Publ., Batavia, IL.

Ehret, D., B. Alsanius, W. Wohanka, J. Menzies, and R. Utkhede. 2001. Disinfestation of recirculating nutrient solutions in greenhouse horticulture. Agronomie $21(4): 323-339$.

Elmer, W., M. Gent, and R. McAvoy. 2012. Partial saturation under ebb and flow irrigation suppresses pythium root rot of ornamentals. Crop Prot. 33:2933 .

Erwin, D.C., S. Bartnicki-Garcia, and P. Tsao. 1983. Phytophthora: Its biology, ecology and pathology. Amer. Phytopathol. Soc., St. Paul, MN. 
Gadgil, A. 1998. Drinking water in developing countries. Annu. Rev. Energy Environ. 23(1):253-286.

Garzón, C.D., J.E. Molineros, J.M. Yánez, F.J. Flores, M. del Mar JiménezGasco, and G.W. Moorman. 2011. Sublethal doses of mefenoxam enhance pythium damping-off of geranium. Plant Dis. 95(10):1233-1238.

Goldberg, N., M. Stanghellini, and S. Rasmussen. 1992. Filtration as a method for controlling pythium root rot of hydroponically grown cucumbers. Plant Dis. 76(8):777-779.

Gubler, F., A. Hardham, and J. Duniec. 1989. Characterising adhesiveness of Phytophthora cinnamomi zoospores during encystment. Protoplasma 149(1):2430 .

Hale, S., K. Hanley, J. Lehmann, A. Zimmerman, and G. Cornelissen. 2011. Effects of chemical, biological, and physical aging as well as soil addition on the sorption of pyrene to activated carbon and biochar. Environ. Sci. Technol. 45(24):10445-10453.

Hausbeck, H. and B. Harlan. 2013a. Pythium root rot in the greenhouse. 8 Sept. 2016. <http://msue.anr.msu.edu/ news/pythium_root_rot_in_the_ greenhouse $>$.

Hausbeck, M.K. and B.R. Harlan. 2013b. Evaluation of fungicides for control of pythium root rot of poinsettia, 2011. Plant Dis. Mgt. Rpt. 7:OT029.

Hausbeck, M.K. and W. Zhang. 2016. Prevent the spread of disease in irrigation water. Greenhouse Grower 2016(Mar):6870 .

Hochmuth, G., D. Maynard, C. Vavrina, E. Hanlon, and E. Simonne. 2004. Plant tissue analysis and interpretation for vegetable crops in Florida. Inst. Food Agr. Sci., Univ. Florida, Gainesville.

Hoitink, H.A.J. 1991. Transmission of plant pathogens in an ebb and flood system. Ohio Florist Assn. Bul. 742:59.

Hong, C., P. Richardson, P. Kong, and E. Bush. 2003. Efficacy of chlorine on multiple species of Phytophthora in recycled nursery irrigation water. Plant Dis. 87(10):1183-1189.

Hong, C.X. and G.W. Moorman. 2005. Plant pathogens in irrigation water: Challenges and opportunities. Crit. Rev. Plant Sci. 24(3):189-208.

Huisman, L. and W. Wood. 1974. Slow sand filtration. World Health Organization, Geneva, Switzerland.
Jamart, G., G.D. Prest, and O. Kamoen. 1988. Control of Pythium spp. on ornamental plants in a nutrient-film system. Mededelingen-Faculteit Landbouwkundige en Rijksuniversiteit Gent 53(2b):625634.

Jeon, S., C.S. Krasnow, C.K. Kirby, L.L. Granke, M.K. Hausbeck, and W. Zhang. 2016. Transport and retention of Phytophthora capsici zoospores in saturated porous media. Environ. Sci. Technol. 50(17):9270-9278.

Kim, H.S., S.H. Lee, Y. Byun, and H.D. Park. 2015. 6-Gingerol reduces Pseudomonas aeruginosa biofilm formation and virulence via quorum sensing inhibition. Sci. Rpt. 5:8656.

Krasnow, C.S. and M.K. Hausbeck. 2017. Influence of $\mathrm{pH}$ and etridiazole on Pythium species. HortTechnology 27:367-374.

Lee, E. and L.R. Oki. 2013. Slow sand filters effectively reduce Phytophthora after a pathogen switch from Fusarium and a simulated pump failure. Water Res. 47(14):5121-5129.

Lewis Ivey, M.L. and S.A. Miller. 2013. Assessing the efficacy of pre-harvest, chlorine-based sanitizers against human pathogen indicator microorganisms and Phytophthora capsici in non-recycled surface irrigation water. Water Res. 47(13): 4639-4651.

Lookabaugh, E.C., K.L. Ivors, and B.B. Shew. 2015. Mefenoxam sensitivity, aggressiveness, and identification of Pythium species causing root rot on floriculture crops in North Carolina. Plant Dis. 99(11): 1550-1558.

MacDonald, J., M. Ali-Shtayeh, J. Kabashima, and J. Stites. 1994. Occurrence of Phytophthora species in recirculated nursery irrigation effluents. Plant Dis. 78(6):607611.

McCauley, A., C. Jones, and J. Jacobsen. 2009. Plant nutrient functions and deficiency and toxicity symptoms. Nutr. Mgt. Module No. 9, Mont. State Univ. Ext., Bozeman.

Meador, D.P., P.R. Fisher, P.F. Harmon, N.A. Peres, M. Teplitski, and C.L. Guy. 2012. Survey of physical, chemical, and microbial water quality in greenhouse and nursery irrigation water. Hort Technology 22:778-786.

Moorman, G., S. Kang, D. Geiser, and S. Kim. 2002. Identification and characterization of Pythium species associated with greenhouse floral crops in Pennsylvania. Plant Dis. 86(11):1227-1231.

Moorman, G. and S. Kim. 2004. Species of Pythium from greenhouses in Pennsylvania exhibit resistance to propamocarb and mefenoxam. Plant Dis. 88(6):630632 .

Oh, M. and J.E. Son. 2008. Phytophthora nicotianae transmission and growth of potted kalanchoe in two recirculating subirrigation systems. Scientia Hort. 119(1):75-78.

Quesada-Ocampo, L.M. and M.K. Hausbeck. 2010. Resistance in tomato and wild relatives to crown and root rot caused by Phytophthora capsici. Phytopathology 100:619-627.

Raabe, R., J. Hurlimann, and T. Byrne. 1981. Chemical and biological approaches to control of pythium root rot of poinsettia. California Plant Pathol. 52: 5-8.

Rahimian, M. and Z. Banihashemi. 1979. A method for obtaining zoospores of Pythium aphanidermatum and their use in determining cucurbit seedling resistance to damping-off. Plant Dis. Rpt. 63(8):658-661.

Raudales, R.E., P.R. Fisher, and C.R. Hall. 2017. The cost of irrigation sources and water treatment in greenhouse production. Irr. Sci. 35(1):43-54.

Runia, W.T. 1993. A review of possibilities for disinfection of recirculation water from soilless cultures. Acta Hort. 382:221229.

Sanogo, S. and G.W. Moorman. 1993. Transmission and control of Pythium aphanidermatum in an ebb-and-flow subirrigation system. Plant Dis. 77(3):287290.

Schuerger, A.C. and W. Hammer. 2009. Use of cross-flow membrane filtration in a recirculating hydroponic system to suppress root disease in pepper caused by Pythium myriotylum. Phytopathology 99(5):597-607.

Sorrenti, G., C.A. Masiello, and M. Toselli. 2016. Biochar interferes with kiwifruit $\mathrm{Fe}$-nutrition in calcareous soil. Geoderma 272:10-19.

Stanghellini, M., D. Kim, S. Rasmussen, and P.A. Rorabaugh. 1996a. Control of root rot of peppers caused by Phytophthora capsici with a nonionic surfactant. Plant Dis. 80(10):1113-1116.

Stanghellini, M., S. Rasmussen, D. Kim, and P.A. Rorabaugh. 1996b. Efficacy of nonionic surfactants in the control of zoospore spread of Pythium aphanidermatum in a recirculating hydroponic system. Plant Dis. 80(4):422-428.

Stephens, C., L. Herr, A. Schmitthenner, and C. Powell. 1983. Sources of Rbizoctonia solani and Pythium spp. in a bedding plant greenhouse. Plant Dis. 67(3):272275. 
Tompkins, C.M. and J.T. Middleton. 1950. Etiology and control of poinsettia root and stem rot caused by Pythium spp. and Rhizoctonia solani. Hilgardia 20:171-182.

Tu, J. and B. Harwood. 2005. Disinfestation of recirculating nutrient solution by filtration as a means to control pythium root rot of tomatoes. Acta Hort. 695:303-307.

Ufer, T., S.K. Werres, M. Posner, and H.P. Wessels. 2008. Filtration to eliminate Phytophthora spp. from recirculating water systems in commercial nurseries. Online Plant Health Prog. 9(1). 24 Feb. 2019. <https://doi.org/2010.1094/ PHP-2008-0314-2001-RS >.

U.S. Department of Agriculture. 2016. Floriculture crops 2015 summary. U.S. Dept. Agr., Natl. Agr. Stat. Serv., Washington, DC. van Der Gaag, D.J., A. Kerssies, and C. Lanser. 2001. Spread of Phytophthora root and crown rot in Saintpaulia, Gerbera and Spathiphyllum pot plants in ebb-and-flowsystems. Eur. J. Plant Pathol. 107(5): 535-542.

van der Plaats-Niterink, A.J. 1981. Monograph of the genus Pythium. Centraalbureau voor Schimmelcultures Baarn, Utrecht, The Netherlands.

van Os, E.A., J.J. Amsing, A.J. van Kuik, and $H$. Willers. 1998. Slow sand filtration: A potential method for the elimination of pathogens and nematodes in recirculating nutrient solutions from glasshouse-grown crops. Acta Hort. 481:519-526.

van Os, E.A., M. Bruins, W. Wohanka, and R. Seidel. 2000. Slow filtration: A technique to minimise the risks of spreading root-infecting pathogens in closed hydroponic systems. Acta Hort. 559:495-502.
Vankuik, A. 1994. Eliminating Phytophthora cinnamomi in a recirculated irrigation system by slow sand filtration. Mededelingen-Faculteit Landbouwkundige en Toegepaste Biologische Wetenschappen Universiteit Gent (Belgium) 59:10591063.

Wellburn, A.R. 1994. The spectral determination of chlorophylls $a$ and $b$, as well as total carotenoids, using various solvents with spectrophotometers of different resolution. J. Plant Physiol. 144(3): 307-313.

World Health Organization. 1996. Rapid sand filtration. WHO Fact Sheets Environ. Sanitation. 27 May 2017. <http:// www.who.int/water_sanitation_health/ hygiene/emergencies/fs2_14.pdf>.

Wohanka, W. and M. Helle. 1996. Suitability of various filter media for slow filtration. Proc. 9th Intl. Congr. Soilless Cult., Wageningen, The Netherlands. p. 551-557. 


\section{Supplemental Material 1. Construction of ebb-and-flow irrigation systems}

To test the effectiveness of filtration units in controlling disease outbreaks in greenhouse-grown poinsettias, six self-contained ebb-and-flow irrigation systems (including optional filtration units) were constructed (Fig. 1). A typical irrigation system consisted of a $8 \times 4 \mathrm{ft}(2.4 \times$ $1.2 \mathrm{~m})$ black plastic ebb-and-flow bench (Hummert, St. Louis, MO), an optional filtration unit, two 130-L (34.3-gal) holding tanks, two $12 \mathrm{~V}$ centrifugal water pumps, two check valves, two auto valves, two water-level sensors, and a timer. Only one holding tank was included in the noninoculated and inoculated control treatments in Expt. 1, and in the inoculated control and "diseased plant" treatments in Expt. 2. Otherwise, the prefilter tank and the holding tank were directly connected for the nonfiltration treatments. The irrigation water was drawn from the prefilter tank by one water pump, passed through a check valve, the filter unit, an auto valve [i.e., 0.5inch $(1.27 \mathrm{~cm})$ motorized ball valve (model MV-2-20-12V-R01-1; MISOL, Jiaxing, China)], and stored in the holding tank until a prescheduled irrigation time controlled by a timer. At the time of irrigation, the irrigation water in the holding tank was pumped into the ebb-and-flow bench via a check valve until reaching a desired watering height [i.e., $1-1.5$ inches $(2.54-3.81 \mathrm{~cm})$ or $10 \mathrm{~min}$ of pumping time]. The two check valves were installed to prevent backflow. One check valve was next to the pump connected to the prefilter tank, and the other next to the pump connected to the holding tank (Fig. 1). The irrigation water in the bench was kept for a desired irrigation period before being drained back to the prefilter tank by opening an auto valve [i.e., the 0.75 -inch $(1.905 \mathrm{~cm})$ motorized ball valve]. Two magnetic float water-level sensors (model all062100ux0008, Uxcell, Kwai Fong, Hong Kong) were installed in the prefilter tank and holding tank, respectively. The water-level sensor in the prefilter tank detects the irrigation water drained from the bench, and the water pump is automatically turned on to deliver the water to the inlet of the filter unit. The second water-level sensor turns off the water pump connected to the holding tank, when the water level reaches the minimum level so as to prevent air entry into the pump.

The filter unit design is described in detail next. Activated carbon (AC) and sand were used as filter media. Operating water pressure of the AC and sand filters was maintained at $6.9 \pm 1.4$ and $5.7 \pm 1.0 \mathrm{kPa}(1.00 \pm$ 0.20 and $0.83 \pm 0.15 \mathrm{psi})$, respectively. Water pressure was measured by a pressure transducer at the top of the filters and recorded in a datalogger (model MCR-4V; T\&D Corp., Matsumoto, Japan). All of the irrigation systems were sterilized before each experiment with a solution of greater than $30 \%$ of household bleach [i.e., $6.15 \%$ sodium hypochlorite $(\mathrm{NaClO})$ solution] was applied in the benches and tanks using sprayers. Any adhering grime or algae was removed using scrub brushes. Then 10 $\mathrm{L}$ (2.6 gal) of $5 \%$ bleach solution was added to the prefilter tank and allowed to recirculate a couple of times in the absence of a filter unit. After cleaning, the systems were thoroughly rinsed several times with tap water and air-dried for several days.

\section{Supplemental Material 2. Filter unit design}

Low-pressure sand and activated carbon (AC) filters were constructed for the greenhouse experiments (Fig. $2)$. Each filter unit was made with a 6 inch $(15.2 \mathrm{~cm})$-diameter PVC pipe of $50 \mathrm{~cm}$ (19.7 inches) in length. The bottom of each filter column was sealed with an end cap fitting, and the top of each filter was assembled with a coupling, an adapter fitting, and a plug fitting in order. Two types of filter media [i.e., sand $(99.69 \%$ silica, Granusil; Unimin Corp., New Canaan, CT) and AC (Filtrasorb 300; CalgonCarbon, Moon Township, PA), were used. The particle size distribution of the sand was $5.1 \%$ 297 to $420 \mu \mathrm{m}, 57.2 \% 420$ to 595 $\mu \mathrm{m}, 36.1 \% 595$ to $841 \mu \mathrm{m}$, and $1.2 \%$ $\geq 841 \mu \mathrm{m}(1 \mu \mathrm{m}=1$ micron $)$. The effective size of AC particles was 0.8 to $1.0 \mathrm{~mm}(0.03-0.04$ inch $)$. A $3-\mathrm{cm}$ (1.2 inch) layer of coarser sand (500$841 \mu \mathrm{m})$ was placed at the bottommost and uppermost layers in the sand filter and bottommost layer in the AC filter to filter out large debris and minimize clogging. The total depth of filter media was $50 \mathrm{~cm}$ including the coarser sand layers. All filter media were used directly without washing. To support the filter media and allow for free drainage of filtered water, two screens each with different size openings [i.e., $0.5 \times 0.5$ inch $(1.27 \mathrm{~cm})$ and $0.25 \times 0.25$ inch $(0.64 \mathrm{~cm})]$ were prepared and bent to be fixed onto about the $2-\mathrm{cm}(0.8$ inch) length of the 6-inch PVC pipe using 12 screws and then mounted inside the end of the bottom cap. A stainless steel screen with $100 \times 100 \mu \mathrm{m}$ opening size was placed on the screens. The top of the filter media was also covered with the $100 \times 100-\mu \mathrm{m}$ and $0.5 \times 0.5$-inch screens similar manner to the bottom part to filter large debris and allow for an even distribution of water flow (Fig. 2). The bottom end cap was drilled and fitted with a 0.5 -inch polypropylene bulkhead tank fitting (TF050; Banjo, Crawfordsville, IN) to connect the outlet pipe with a union fitting (Mueller/B\&K, Collierville, TN) and a 0.5 -inch motorized ball valve (MISOL, Jiaxing, China). The motorized ball valve was open during the operation of the pump connected to the prefilter tank. The pressure sensors were installed at the inlet of each filter. All of the components were assembled and sealed to make watertight columns. 

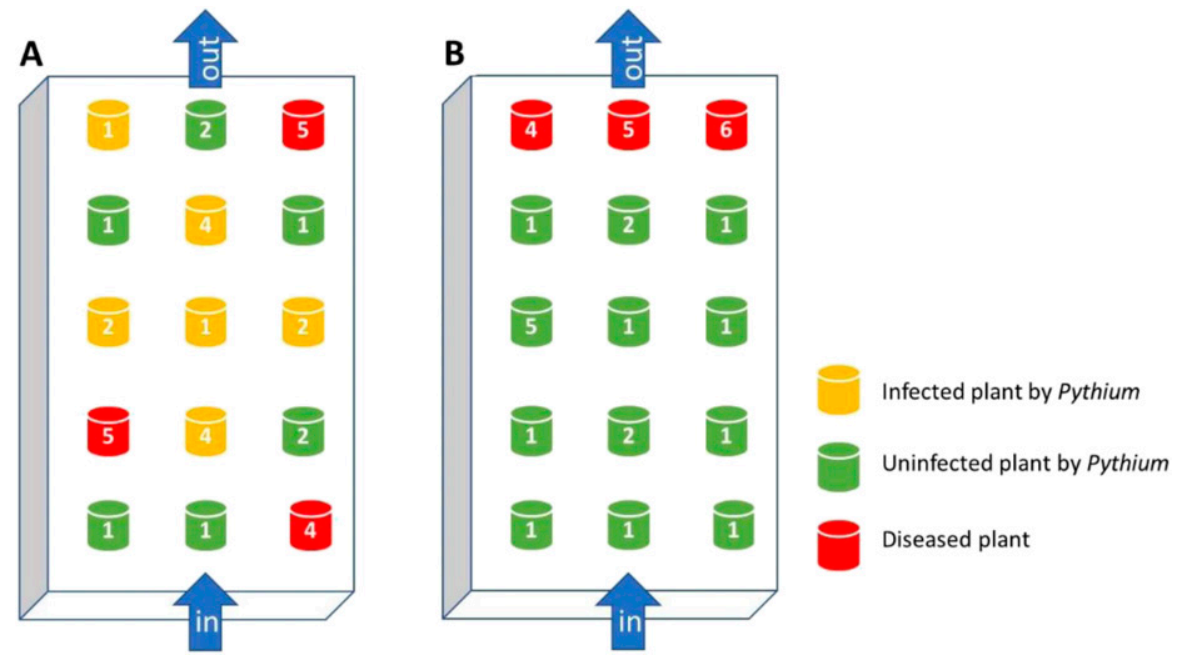

Supplemental Fig. 1. Location of preinoculated plants (red), infected plants (yellow), and healthy plants (green) at the end of the diseased plant treatment in Expts. 1 (A) and 2 (B). Expts. 1 and 2 were performed to assess the effectiveness of rapid filtration and fungicide application to control pythium root rot of poinsettia in greenhouse. Irrigation water in constructed ebb-and-flow recirculating irrigation systems was inoculated with encysted Pythium aphanidermatum zoospores at $68 \pm 36$ zoospores $/ \mathrm{mL}(2011.0 \pm 1064.6$ zoospores $/ \mathrm{fl} \mathrm{oz})$ at the initiation and then 2 and 4 weeks afterward in each experiment. The infested planting pots were placed randomly in Expt. 1, but at the back location near the drainage of the bench in Expt. 2 . Expt. 1 experienced the interruption of the dark period. The number in the column is the root rot severity. A positive plant was identified by the isolation of $P$. aphanidermatum.
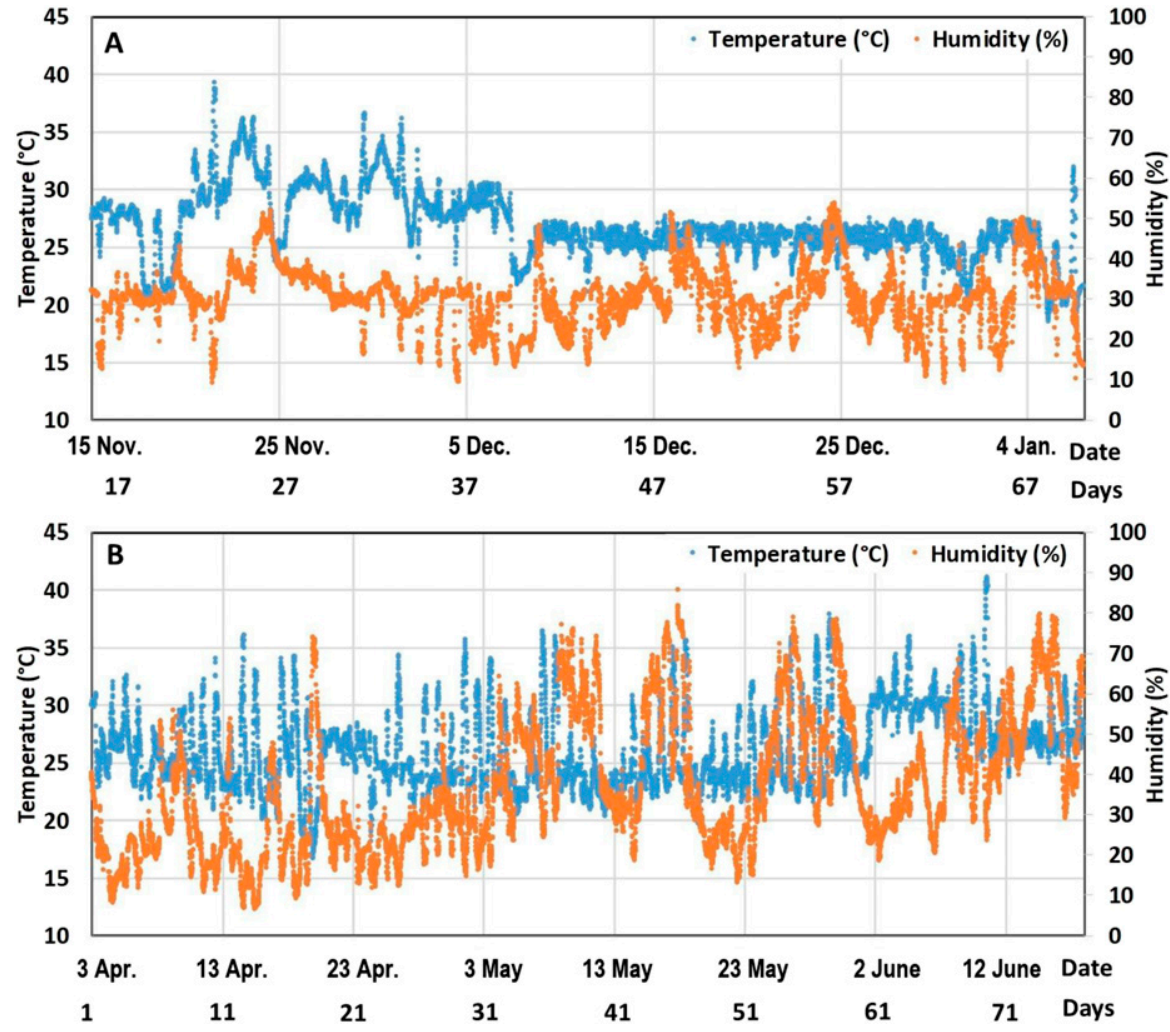

Supplemental Fig. 2. Air temperature and relative humidity in Expts. 1 (A) and 2 (B). Expts. 1 and 2 were performed to assess the effectiveness of rapid filtration and fungicide application to control pythium root rot of poinsettia in greenhouse. Irrigation water in constructed ebb-and-flow recirculating irrigation systems was inoculated with encysted Pythium aphanidermatum zoospores at $68 \pm 36$ zoospores $/ \mathrm{mL}(2011.0 \pm 1064.6$ zoospores $/ \mathrm{fl} \mathrm{oz})$ at the initiation and then 2 and 4 weeks afterward in each experiment; $\left({ }^{\circ} \mathrm{C} \times 1.8\right)+32={ }^{\circ} \mathrm{F}$. 

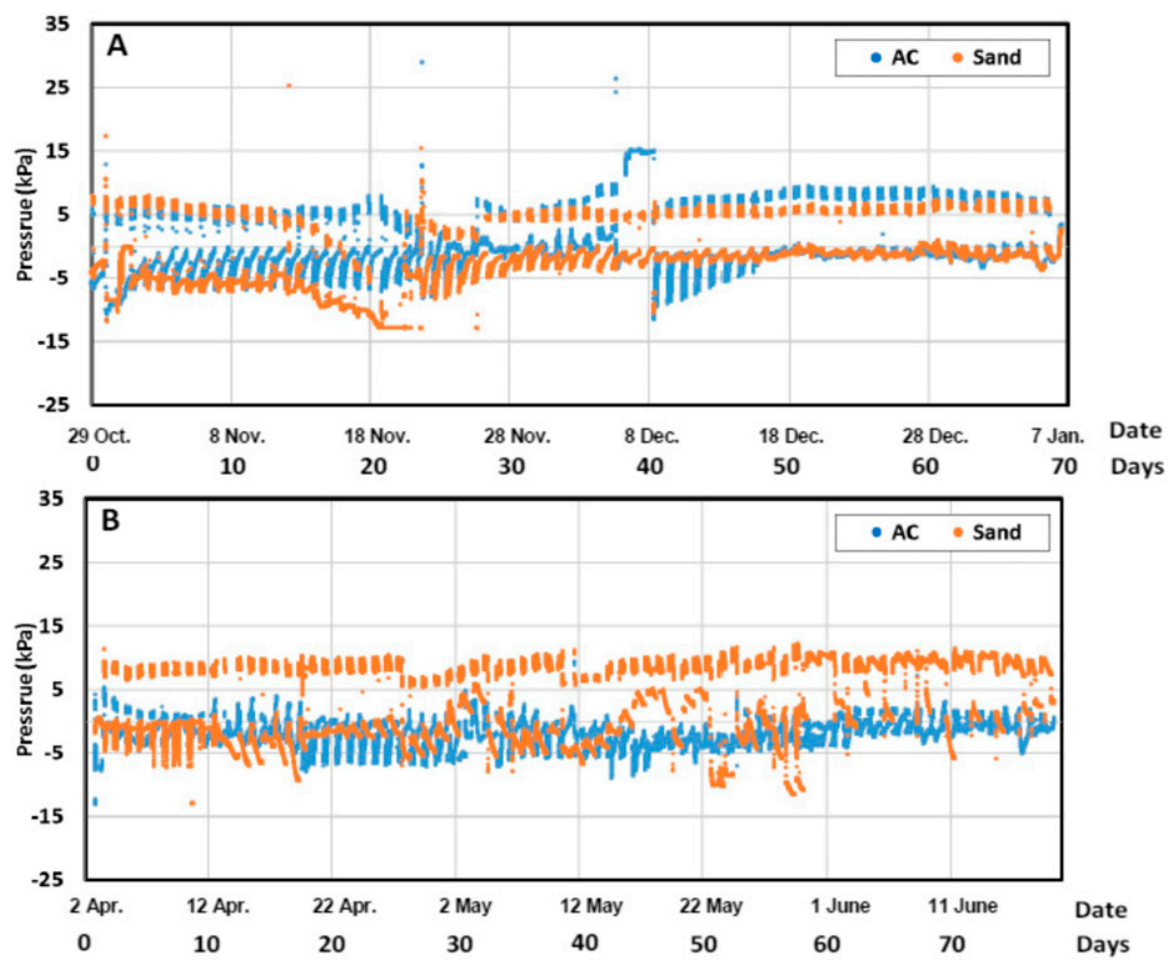

Supplemental Fig. 3. Water pressure in the activated carbon (AC) and sand filters in Expts. 1 (A) and 2 (B). Expts. 1 and 2 were performed to assess the effectiveness of rapid filtration and fungicide application to control pythium root rot of poinsettia in greenhouse. Irrigation water in constructed ebb-and-flow recirculating irrigation systems was inoculated with encysted Pythium aphanidermatum zoospores at $68 \pm 36$ zoospores $/ \mathrm{mL}(2011.0 \pm 1064.6$ zoospores $/ \mathrm{fl} \mathrm{oz})$ at the initiation and then 2 and 4 weeks afterward in each experiment. Sand = inoculated irrigation water treatment with the sand filter; Activated carbon = inoculated irrigation water treatment with the activated carbon filter. Sand and activated filters were used to remove $P$. aphanidermatum zoospores from infested irrigation water; $1 \mathrm{kPa}=0.1450 \mathrm{psi}$. 

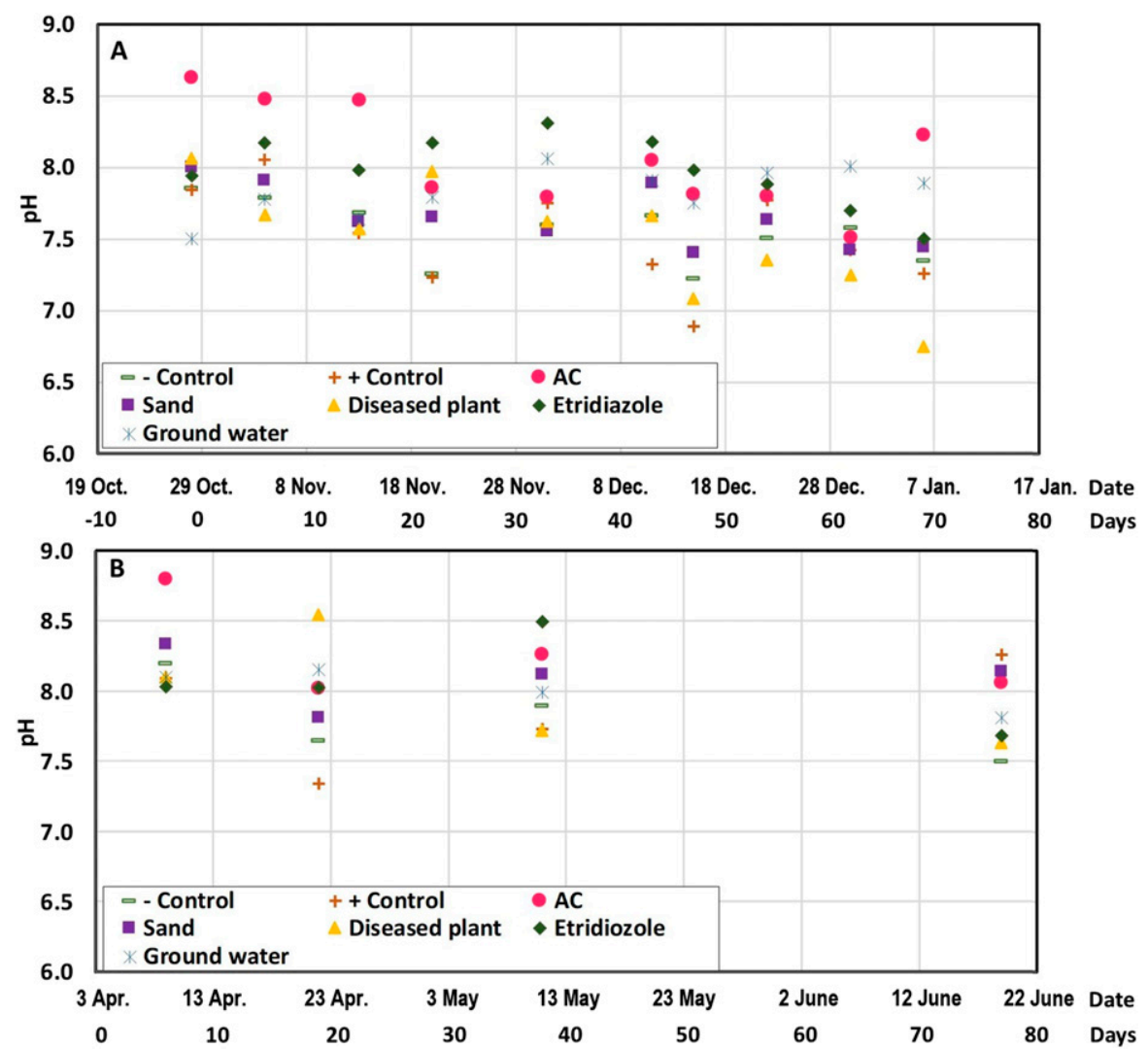

Supplemental Fig. 4. pH of irrigation water measured in Expts. 1 (A) and 2 (B). Expts. 1 and 2 were performed to assess the effectiveness of rapid filtration and fungicide application to control pythium root rot of poinsettia in greenhouse, including six treatments: - Control $=$ noninoculated irrigation water treatment without filtration or pathogen; + Control $=$ inoculated irrigation water treatment without filtration or fungicide; $A C=$ inoculated irrigation water treatment with the activated carbon filter; Sand = inoculated irrigation water treatment with the sand filter; Diseased plant $=$ diseased plant treatment in the absence of any filters; Etridiazole = inoculated irrigation water treatment with the fungicide (etridiazole) application in the absence of any filters. Irrigation water in constructed ebb-and-flow recirculating irrigation systems was inoculated with encysted Pythium aphanidermatum zoospores at $68 \pm 36$ zoospores $/ \mathrm{mL}(2011.0 \pm 1064.6 \mathrm{zoospores} / \mathrm{fl} \mathrm{oz})$ at the initiation and then 2 and 4 weeks afterward in each experiment. Sand and activated filters were used to remove $P$. aphanidermatum zoospores from infested irrigation water. The infested planting pots were placed randomly in Expt. 1, but at the back location near the drainage of the bench in Expt. 2. 

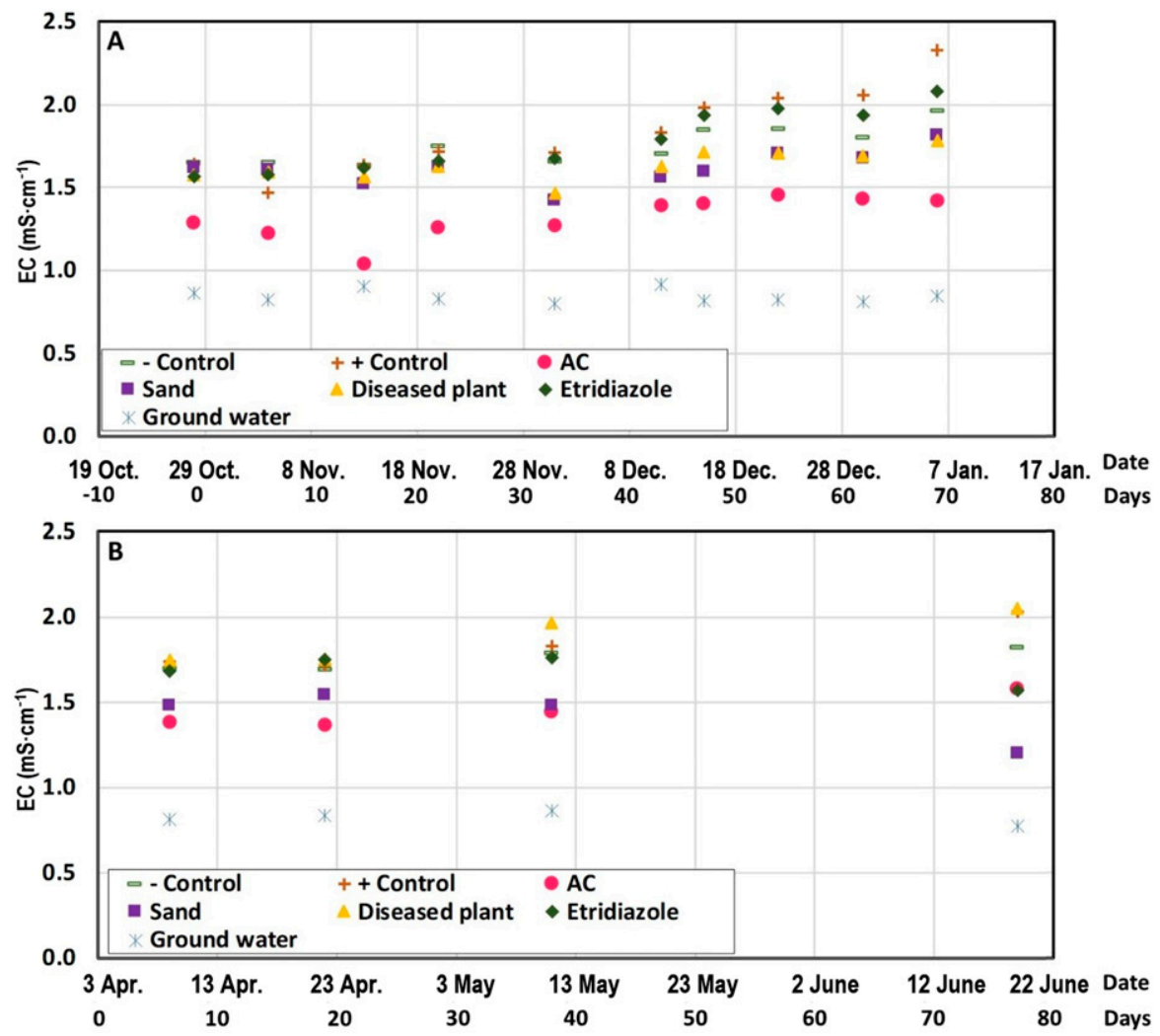

Supplemental Fig. 5. Electrical conduction (EC) of irrigation water measured in Expts. 1 (A) and 2 (B). Expts. 1 and 2 were performed to assess the effectiveness of rapid filtration and fungicide application to control pythium root rot of poinsettia in greenhouse, including six treatments: - Control = noninoculated irrigation water treatment without filtration or pathogen; + Control = inoculated irrigation water treatment without filtration or fungicide; $\mathrm{AC}=$ inoculated irrigation water treatment with the activated carbon filter; Sand $=$ inoculated irrigation water treatment with the sand filter; Diseased plant $=$ diseased plant treatment in the absence of any filters; Etridiazole = inoculated irrigation water treatment with the fungicide (etridiazole) application in the absence of any filters. Irrigation water in constructed ebb-and-flow recirculating irrigation systems was inoculated with encysted Pythium aphanidermatum zoospores at $68 \pm 36$ zoospores $/ \mathrm{mL}(2011.0 \pm 1064.6 \mathrm{zoospores} / \mathrm{fl} \mathrm{oz})$ at the initiation and then 2 and 4 weeks afterward in each experiment. Sand and activated filters were used to remove $P$.

aphanidermatum zoospores from infested irrigation water. The infested planting pots were placed randomly in Expt. 1 but at the back location near the drainage of the bench in Expt. $2 ; 1 \mathrm{mS} \cdot \mathrm{cm}^{-1}=1 \mathrm{mmho} / \mathrm{cm}$. 

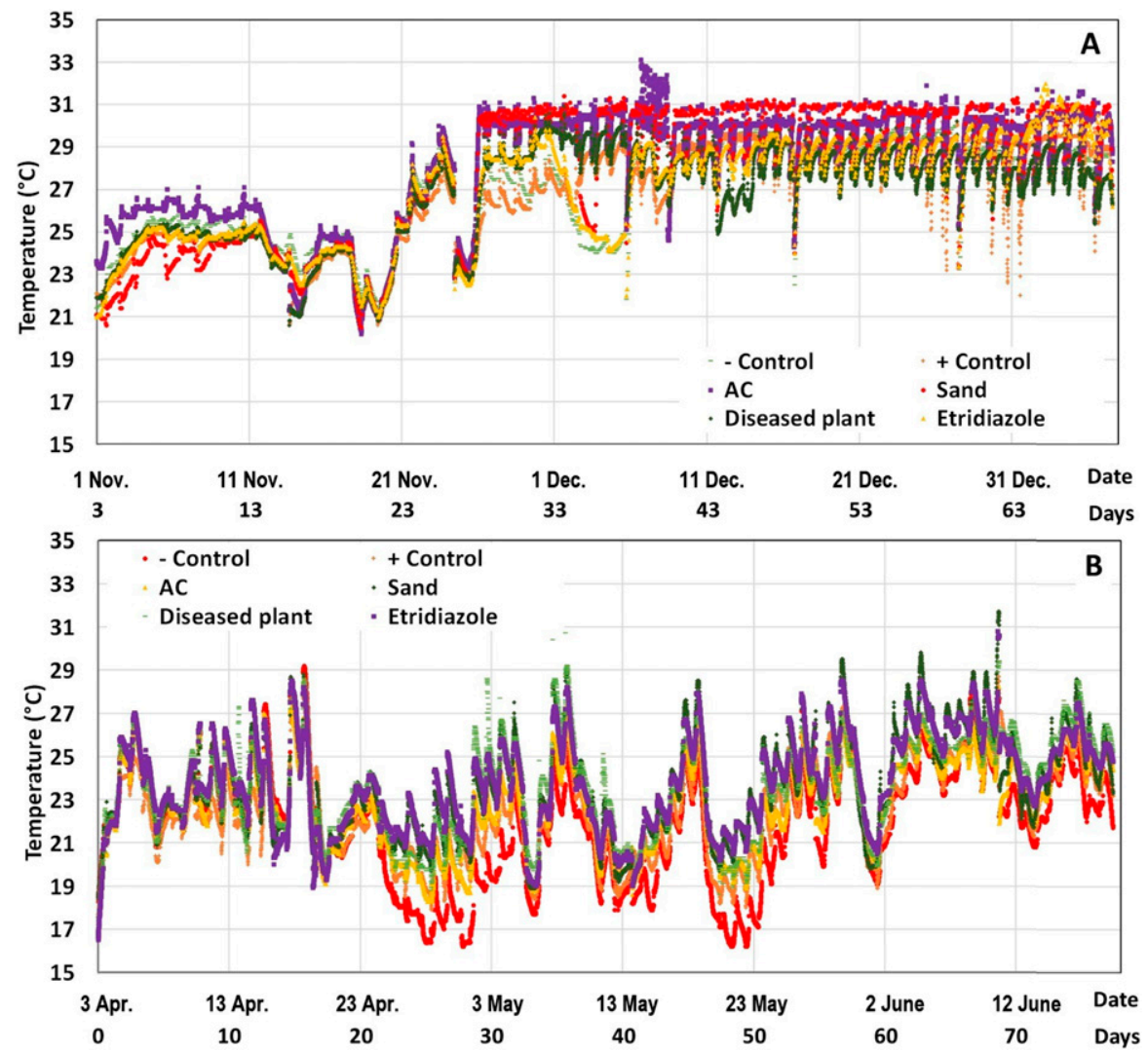

Supplemental Fig. 6. Irrigation water temperature in the holding tank for Expts. 1 (A) and 2 (B). Expts. 1 and 2 were performed to assess the effectiveness of rapid filtration and fungicide application to control pythium root rot of poinsettia in greenhouse, including six treatments: - Control = noninoculated irrigation water treatment without filtration or pathogen; + Control = inoculated irrigation water treatment without filtration or fungicide; AC = inoculated irrigation water treatment with the activated carbon filter; Sand = inoculated irrigation water treatment with the sand filter; Diseased plant $=$ diseased plant treatment in the absence of any filters; Etridiazole = inoculated irrigation water treatment with the fungicide (etridiazole) application in the absence of any filters. Irrigation water in constructed ebb-and-flow recirculating irrigation systems was inoculated with encysted Pythium aphanidermatum zoospores at $68 \pm 36$ zoospores $/ \mathrm{mL}(2011.0 \pm 1064.6 \mathrm{zoospores} / \mathrm{fl} \mathrm{oz})$ at the initiation and then 2 and 4 weeks afterward in each experiment. Sand and activated filters were used to remove $P$. aphanidermatum zoospores from infested irrigation water. The infested planting pots were placed randomly in Expt. 1 , but at the back location near the drainage of the bench in Expt. $2 ;\left({ }^{\circ} \mathrm{C} \times 1.8\right)+32={ }^{\circ} \mathrm{F}$. 

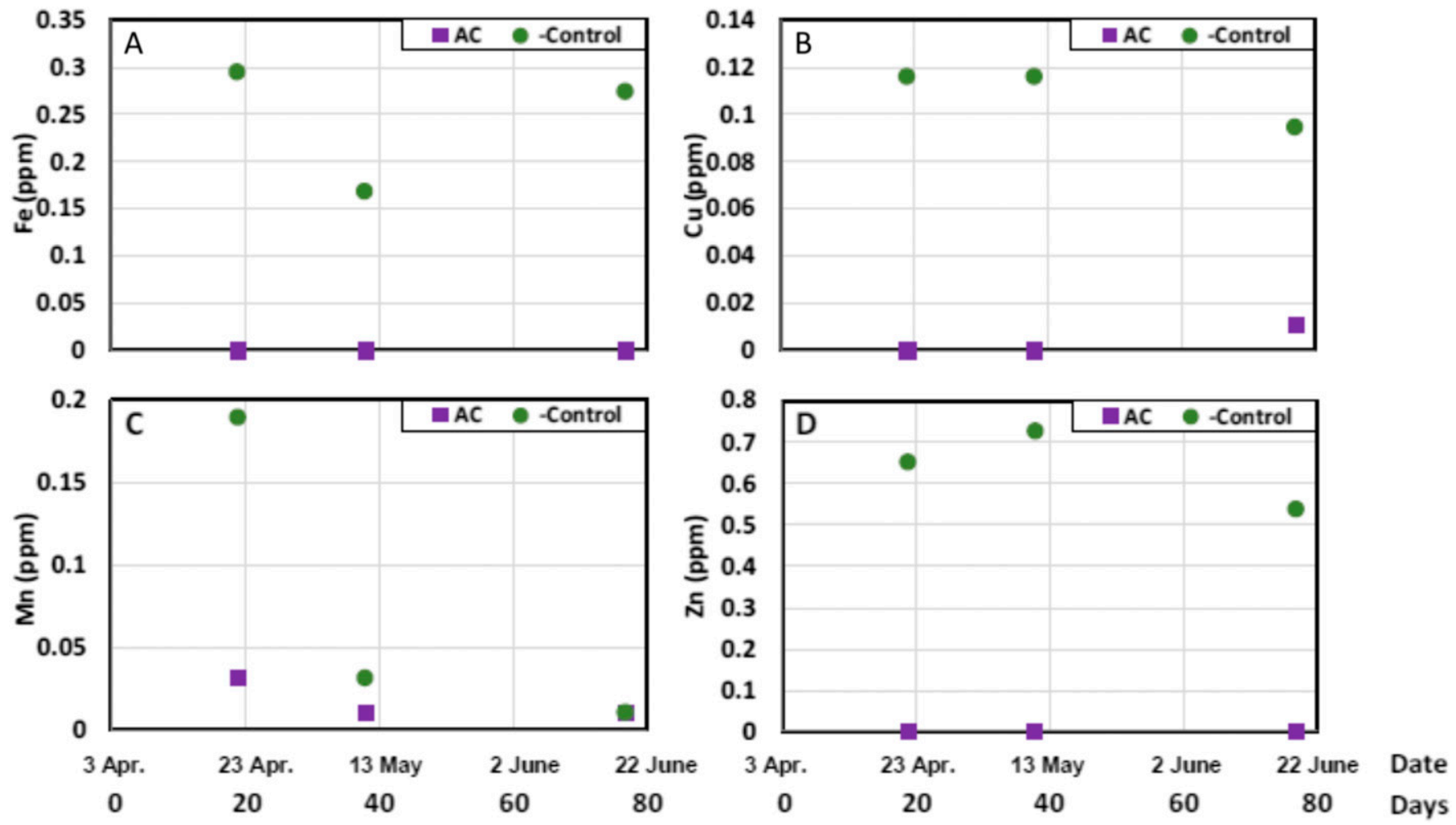

Supplemental Fig. 7. Micronutrient concentrations [iron (Fe), copper $(\mathrm{Cu})$, manganese $(\mathrm{Mn})$, and zinc $(\mathrm{Zn})$ ] in the irrigation water in the activated carbon (AC) filter and noninoculated control treatments during Expt. 2. Expt. 2 was performed to assess the effectiveness of rapid filtration and fungicide application to control pythium root rot of poinsettia in greenhouse. Irrigation water in constructed ebb-and-flow recirculating irrigation systems was inoculated with encysted Pythium aphanidermatum zoospores at $68 \pm 36$ zoospores $/ \mathrm{mL}(2011.0 \pm 1064.6$ zoospores $/ \mathrm{fl} \mathrm{oz})$ at the initiation of the experiment and then 2 and 4 weeks afterward; $1 \mathrm{ppm}=\mathrm{mg} \cdot \mathrm{L}^{-1}$.
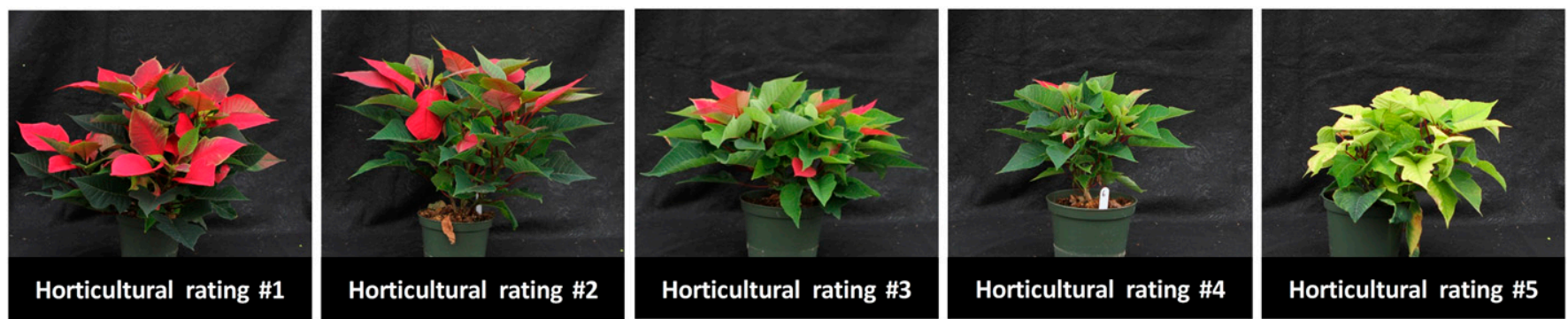

Supplemental Fig. 8. Horticultural rating scale in Expt. 2 (\#1 = high aesthetic quality, and \#5 = no aesthetic value). Expt. 2 was performed to assess the effectiveness of rapid filtration and fungicide application to control pythium root rot of poinsettia in greenhouse. Irrigation water in constructed ebb-and-flow recirculating irrigation systems was inoculated with encysted Pythium aphanidermatum zoospores at $68 \pm 36$ zoospores $/ \mathrm{mL}(2011.0 \pm 1064.6$ zoospores $/ \mathrm{fl} \mathrm{oz})$ at the initiation of the experiment and then 2 and 4 weeks afterward. 


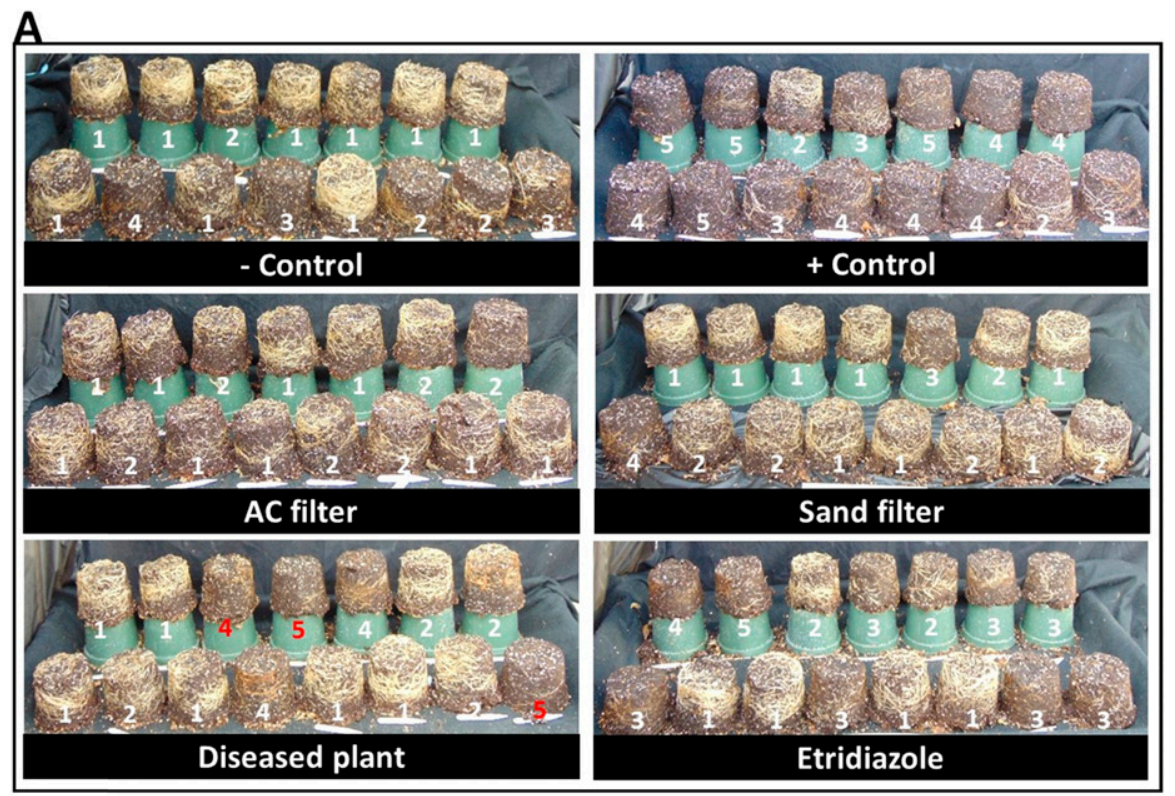

B

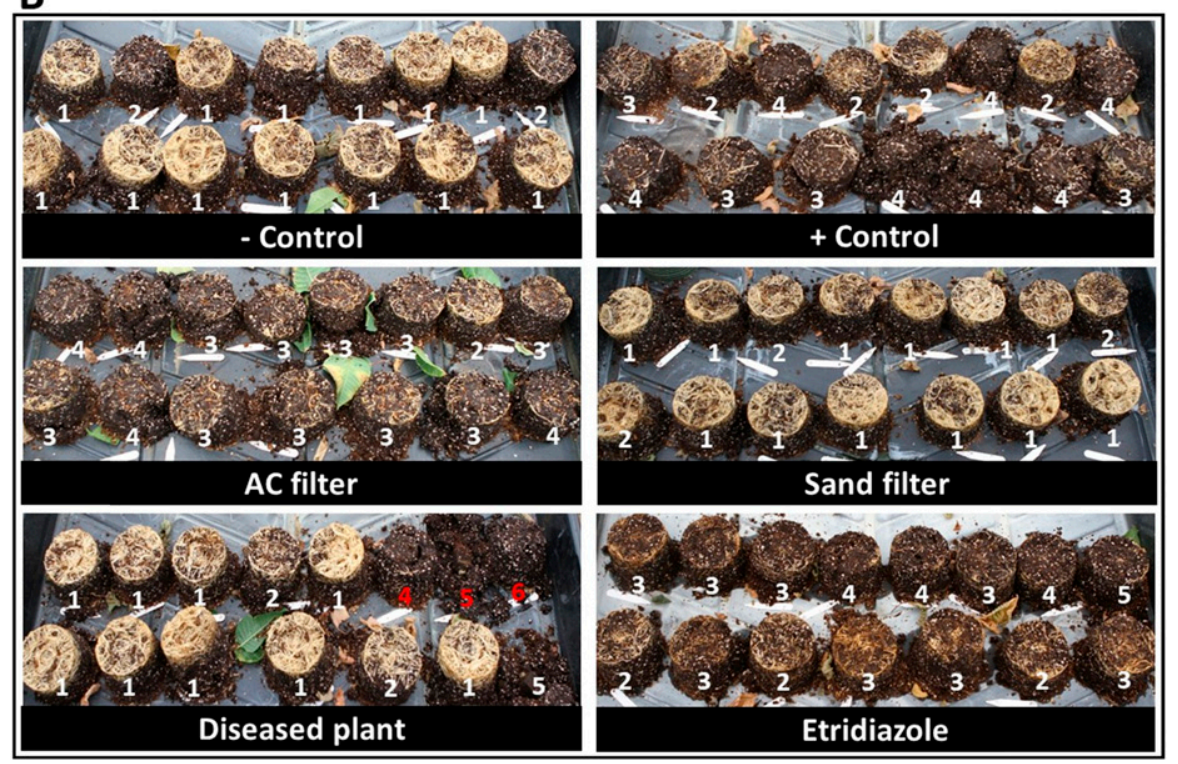

Supplemental Fig. 9. Poinsettia roots for evaluating root necrosis in Expts. 1 (A) and 2 (B). Expts. 1 and 2 were performed to assess the effectiveness of rapid filtration and fungicide application to control pythium root rot of poinsettia in greenhouse, including six treatments: - Control = noninoculated irrigation water treatment without filtration or pathogen; + Control = inoculated irrigation water treatment without filtration or fungicide; $A C=$ inoculated irrigation water treatment with the activated carbon filter; Sand $=$ inoculated irrigation water treatment with the sand filter; Diseased plant $=$ diseased plant treatment in the absence of any filters; Etridiazole = inoculated irrigation water treatment with the fungicide (etridiazole) application in the absence of any filters. Irrigation water in constructed ebb-and-flow recirculating irrigation systems was inoculated with encysted Pythium aphanidermatum zoospores at $68 \pm 36$ zoospores $/ \mathrm{mL}(2011.0 \pm 1064.6 \mathrm{zoospores} / \mathrm{fl} \mathrm{oz})$ at the initiation and then 2 and 4 weeks afterward in each experiment. Sand and activated filters were used to remove $P$.

aphanidermatum zoospores from infested irrigation water. The infested planting pots were placed randomly in Expt. 1, but at the back location near the drainage of the bench in Expt. 2. White roots indicate a healthy root system, and dark roots and dispersed growing media are symptoms of root rot. The number is the root rot severity rating. Root rot severity was rated per the following scale: 1 = no symptoms; 2 = mild root rot, less than one-third of plant roots affected; $3=$ intermediate root rot, one-third to two-thirds of plant roots affected; 4 = severe root rot, more than two-thirds of plant roots affected; $5=$ severe root and crown rot; and $6=$ dead plant. 


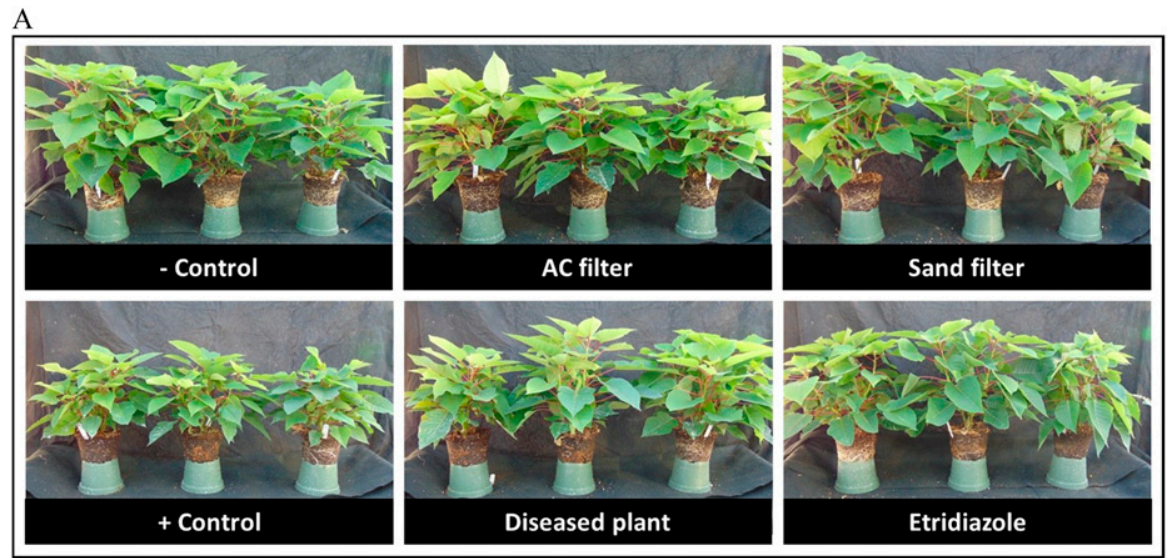

B
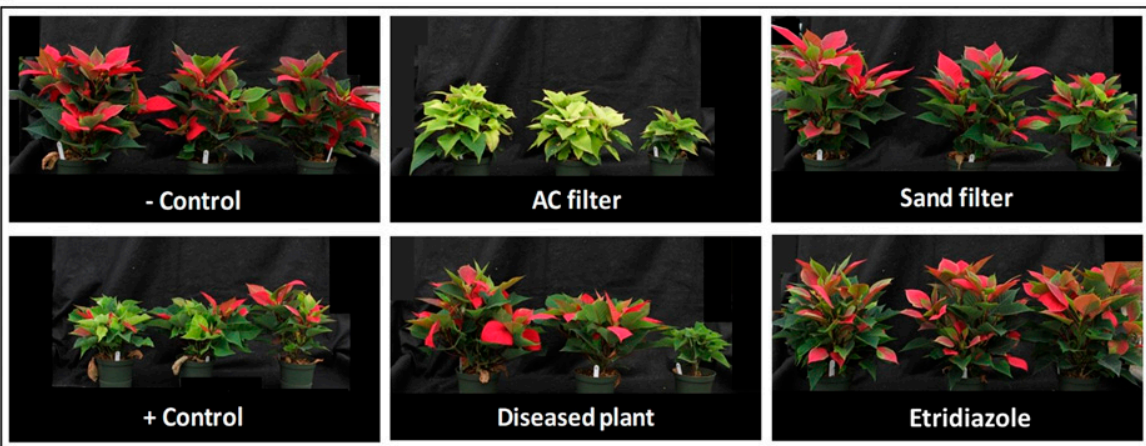

Supplemental Fig. 10. Poinsettia plants, representative of the range of plant quality, at the end of Expt. 1 (A) (69 d after inoculation with Pythium aphanidermatum zoospores) and Expt. 2 (B) (78 d after inoculation with P. aphanidermatum zoospores). Expts. 1 and 2 were performed to assess the effectiveness of rapid filtration and fungicide application to control pythium root rot of poinsettia in greenhouse, including six treatments: - Control = noninoculated irrigation water treatment without filtration or pathogen; + Control = inoculated irrigation water treatment without filtration or fungicide; AC = inoculated irrigation water treatment with the activated carbon filter; Sand = inoculated irrigation water treatment with the sand filter; Diseased plant $=$ diseased plant treatment in the absence of any filters; Etridiazole = inoculated irrigation water treatment with the fungicide (etridiazole) application in the absence of any filters. Irrigation water in constructed ebb-andflow recirculating irrigation systems was inoculated with encysted $P$. aphanidermatum zoospores at $68 \pm 36$ zoospores $/ \mathrm{mL}$ $(2011.0 \pm 1064.6$ zoospores $/ \mathrm{fl} \mathrm{oz})$ at the initiation and then 2 and 4 weeks afterward in each experiment. Sand and activated filters were used to remove $P$. aphanidermatum zoospores from infested irrigation water. The infested planting pots were placed randomly in Expt. 1 but at the back location near the drainage of the bench in Expt. 2. 


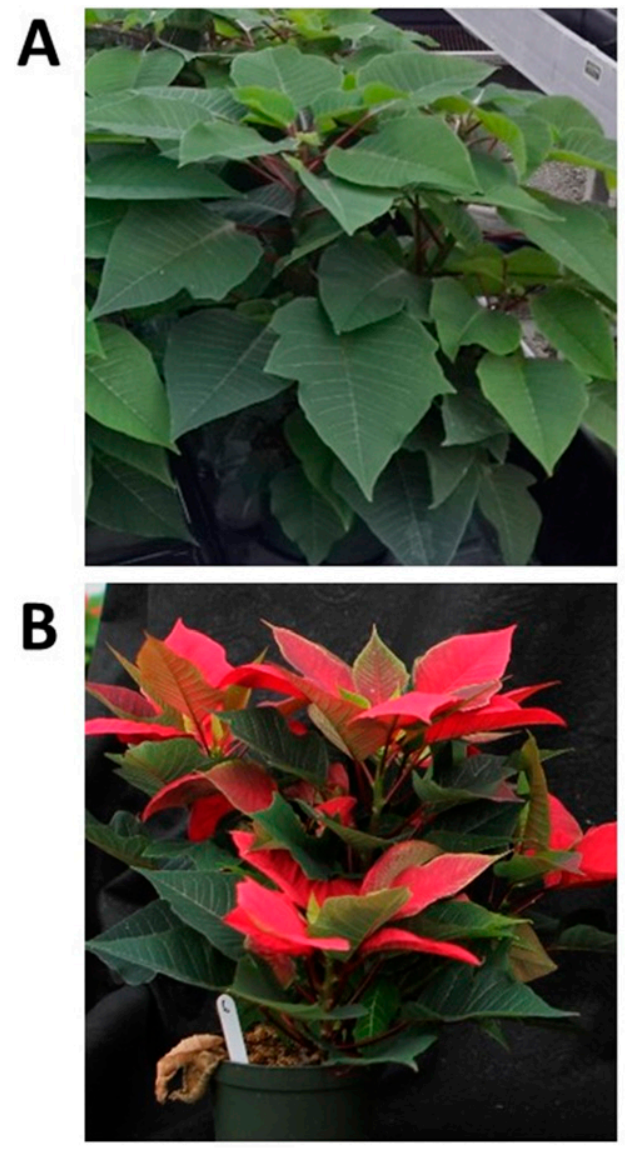

\section{Uninoculated control}
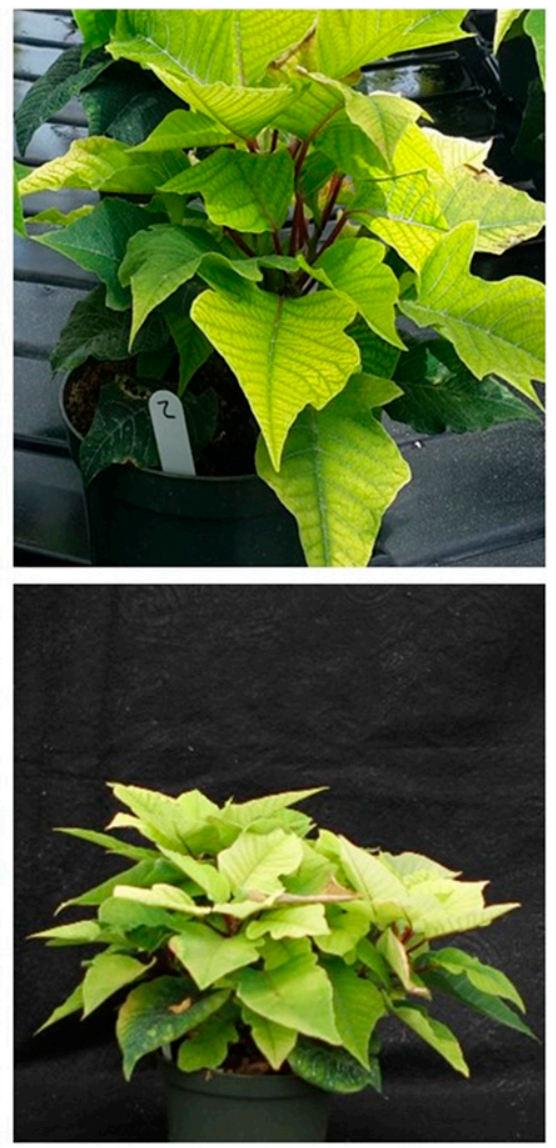

\section{AC filter treatment}

Supplemental Fig. 11. Color of leaves comparison between noninoculated control and activated carbon (AC) filter treatments in Expts. 1 (A) and 2 (B). Expts. 1 and 2 were performed to assess the effectiveness of rapid filtration and fungicide application to control pythium root rot of poinsettia in greenhouse. Irrigation water in constructed ebb-and-flow recirculating irrigation systems was inoculated with encysted Pythium aphanidermatum zoospores at $68 \pm 36$ zoospores $/ \mathrm{mL}(2011.0 \pm 1064.6$ zoospores $/ \mathrm{fl} \mathrm{oz}$ ) at the initiation and then 2 and 4 weeks afterward in each experiment. 
Supplemental Table 1. Nutrient concentrations in the irrigation water during Expts. 1 and 2.

\begin{tabular}{|c|c|c|c|c|c|c|c|c|c|c|c|c|c|c|c|c|c|c|}
\hline \multirow{3}{*}{ Treatments ${ }^{\mathrm{z}}$} & \multicolumn{18}{|c|}{ Nutrients $\left(\mathrm{mg} \cdot \mathrm{L}^{-1}\right)^{\mathrm{y}}$} \\
\hline & \multicolumn{3}{|c|}{ Nitrate } & \multicolumn{3}{|c|}{ Phosphorus } & \multicolumn{3}{|c|}{ Potassium (K) } & \multicolumn{3}{|c|}{ Calcium } & \multicolumn{3}{|c|}{ Magnesium } & \multicolumn{3}{|c|}{ Sodium } \\
\hline & \multicolumn{18}{|c|}{ Expt. $1(d)^{x}$} \\
\hline -Control & 92 & 128 & 172 & 7.7 & 9.7 & 8.8 & 111 & 117 & 135 & 95 & 123 & 150 & 38 & 47 & 59 & 16 & 21 & 29 \\
\hline +Control & 88 & 128 & 263 & 7.5 & 6.8 & 8.8 & 100 & 109 & 149 & 95 & 123 & 177 & 41 & 60 & 73 & 16 & 22 & 38 \\
\hline Sand & 91 & 117 & 150 & 6.2 & 7 & 8.6 & 91 & 96 & 109 & 95 & 123 & 136 & 35 & 45 & 53 & 16 & 21 & 26 \\
\hline Diseased plant & 85 & 116 & 151 & 6.6 & 5.6 & 14.5 & 94 & 107 & 110 & 95 & 123 & 123 & 36 & 48 & 51 & 16 & 20 & 23 \\
\hline \multirow[t]{2}{*}{ Ground water } & 0 & n.a. & n.a. & 0.4 & n.a. & n.a. & 2 & n.a. & n.a. & 109 & n.a. & n.a. & 36 & n.a & n.a. & 17 & n.a. & n.a. \\
\hline & \multicolumn{18}{|c|}{ Expt. $2(d)^{x}$} \\
\hline Treatments $^{\mathrm{y}}$ & 5 & 38 & 78 & 5 & 38 & 78 & 5 & 38 & 78 & 5 & 38 & 78 & 5 & 38 & 78 & 5 & 38 & 78 \\
\hline Etridiazole & 83 & 98 & 80 & 6.4 & 2.8 & 4.4 & 103 & 123 & 100 & 123 & 109 & 109 & 45 & 54 & 47 & 31 & 36 & 27 \\
\hline Diseased plant & 88 & 163 & 163 & 7 & 4.7 & 3.7 & 106 & 147 & 147 & 123 & 164 & 164 & 45 & 62 & 63 & 25 & 31 & 28 \\
\hline Ground water & 0 & n.a. & n.a. & 0.1 & n.a. & n.a. & 2 & n.a. & n.a. & 95 & n.a. & n.a. & 35 & n.a. & n.a. & 15 & n.a. & n.a. \\
\hline \multicolumn{19}{|c|}{ 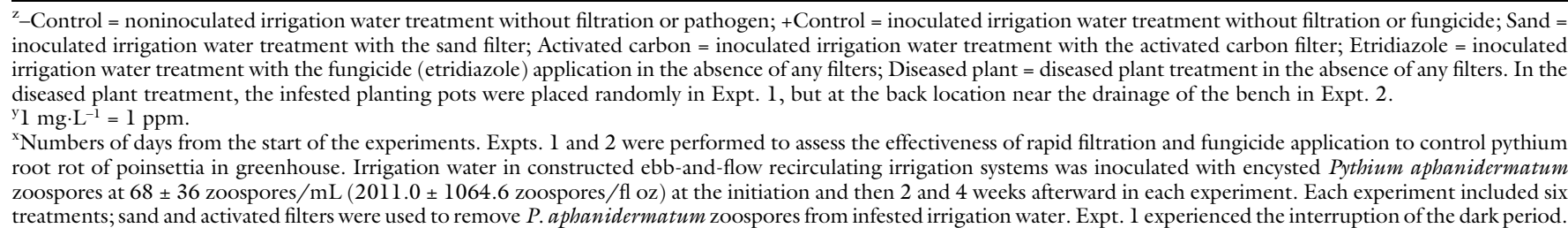 } \\
\hline
\end{tabular}

